\title{
Nasogastric/nasoenteric tube-related adverse events: an integrative review*
}

\author{
Ana Paula Gobbo Motta ${ }^{1}$ \\ (iD) https://orcid.org/0000-0002-4319-3549 \\ Mayara Carvalho Godinho Rigobello ${ }^{1}$ \\ (1D) https://orcid.org/0000-0002-3633-7225 \\ Renata Cristina de Campos Pereira Silveira ${ }^{1}$ \\ (iD) https://orcid.org/0000-0002-2883-3640 \\ Fernanda Raphael Escobar Gimenes \\ (D) https://orcid.org/0000-0002-5174-112X
}

Objective: to analyze in the scientific literature the evidence on nasogastric/nasoenteric tube related adverse events in adult patients. Method: integrative literature review through the search of publications in journals indexed in PubMed/ MEDLINE, CINAHL, LILACS, EMBASE and Scopus, and hand searching, was undertaken up to April 2017. Results: the sample consisted of 69 primary studies, mainly in English and published in the USA and UK. They were divided in two main categories and subcategories: the first category refers to Mechanical Adverse Events (respiratory complications; esophageal or pharyngeal complications; tube obstruction; intestinal perforation; intracranial perforation and unplanned tube removal) and the second alludes to Others (pressure injury related to fixation and misconnections). Death was reported in 16 articles. Conclusion: nasogastric/nasoenteric tube related adverse events are relatively common and the majority involved respiratory harm that resulted in increased hospitalization and/or death. The results may contribute to healthcare professionals, especially nurses, to develop an evidence-based guideline for insertion and correct positioning of bedside enteral tubes in adult patients.

Descriptors: Enteral Nutrition; Intubation, Gastrointestinal; Nursing; Patient Safety; Review; Patient Harm.

\section{How to cite this article}

Motta APG, Rigobello MCG, Silveira RCCP, Gimenes FRE. Nasogastric/nasoenteric tube-related adverse events: an integrative review. Rev. Latino-Am. Enfermagem. 2021;29:e3400. [Access † - 1 ]; Available in: DOI: http://dx.doi.org/10.1590/1518-8345.3355.3400. 


\section{Introduction}

The insertion of a nasogastric/nasoenteric tube (NGT/NET) is a common practice in acute and chronic care settings for the delivery of feeding and/or medications to patients of all ages(1). This procedure may lead to adverse events (AEs) ${ }^{(2)}$ though, defined as an incident that resulted in patient harm or an injury that was caused by medical management or complications instead of the underlying disease and that resulted in prolonged hospitalization or disability at the time of discharge from medical care, or both(3).

In the worldwide literature there are many reports of deaths associated with these tubes ${ }^{(4)}$. According to the Food and Drug Administration (FDA), from January 2012 to July 2017, there were 51 reports of pneumothorax related with NGT/ NET placement. In most cases, urgent intervention was required, including needle decompression or chest tube insertion. Several of these events were associated with cardiopulmonary arrest and death ${ }^{(5)}$.

Another report from the National Patient Safety Agency (NPSA) showed that about 170,000 NGT/ NETs are inserted per year for enteral nutrition and medication administration in the United Kingdom (UK). According to the NPSA, between 2005 and 2010, 21 deaths and 79 severe AEs caused by NGT/ NET displacement were reported to the UK National Reporting and Learning System (NRLS), contributing to poor patient outcomes ${ }^{(6-7)}$.

In Brazil, severe and fatal NGT/NET-related AEs have been reported in the media. These events were mainly caused by misconnection, which resulted in the infusion of enteral nutrition into the vein ${ }^{(8)}$. Research conducted in the USA showed that up to $3.2 \%$ NGT/NET were inserted into the airway, resulting in pneumothorax and death ${ }^{(9-10)}$.

The inadvertent introduction of an NGT/NET into the tracheal tree results in patient discomfort, delayed eating, increased morbidity, mortality and the length of hospital stay. Nonetheless, other AEs related with NGT/NET insertion may occur, such as sinusitis, nasopharyngeal discomfort, nasal septum erosion, pressure injury, epistaxis and blood return through the tube in guidewire withdrawal. NGT/NET insertion can also cause pain, discomfort, vomiting and refusal of the procedure by the patients ${ }^{(9)}$. Thus, nurses should be aware of these risks in order to improve patient safety. In addition, the nursing care provided needs to be guided by Evidence-Based Practice $(\mathrm{EBP})^{(10)}$.

Although NGT/NET-related AEs are common in hospitals settings with significant morbidity and mortality, the issue has not been extensively studied, especially in developing countries(11). In Brazil, data on this topic is not available, however, it is observed that the use of these tubes are common in most Brazilian healthcare institutions ${ }^{(12)}$. Studies that aim to identify the types and the most frequent NGT/NETrelated AEs can reduce that gap and the risks of harm caused to patients and lower overall cost of care(11).

The lack of background studies on feeding tube-related AEs poses a difficult challenge, but at the same time highlights the importance of this study as a first essential step towards improving patient safety. Thus, the purpose of this integrative review was to analyze in the scientific literature the evidence on nasogastric/nasoenteric tube related adverse events in adult patients.

\section{Method}

An integrative review was conducted in six phases $^{(13)}$ in April 2017: selection of research question; literature search; categorization of data; analysis of studies included in review; interpretation and synthesis of outcomes and presentation of review. Beyond that, PRISMA guidelines(14) ${ }^{(14)}$ we followed.

The search strategy for the articles and the research question were developed through the PICO strategy ${ }^{(14)}$ : The population refers to adult patients $(P)$; the intervention, to patients with SNG/SNE (I); there was no comparison group (C) and the outcome refers to the main adverse events (O). The following research question was asked: what are the main AEs in adult patients with SNG/SNE? To perform the search strategy, keywords were used that reflected the research question, with the boolean operators AND and OR.

The most relevant electronic databases for nurses were used: PubMed/MEDLINE, CINAHL, LILACS, EMBASE and Scopus. In addition, we used hand searching to check the reference lists of selected studies to see if these references included reports of other studies that could be eligible for this review.

The following search strategy was used: [(nasogastric tube) OR (feeding tube) OR (enteral 
tube) OR (enteral tube feeding) OR (nasogastric feeding tube) OR (nasoenteral tube)] AND [(medical errors) OR (adverse events) OR (adverse event) OR incidents OR incident OR mistakes OR mistake].

After completing the search, performed by two independent researchers, all articles were exported to EndNote Web Basic (Clarivate Analytics ${ }^{\circledR}$ ) and duplicated articles were removed. The eligibility criteria were established based on the review question. Thus, primary studies were included which addressed NGT/NET-related AEs in adult patients (> 18 years); published in Portuguese, Spanish and English; and no publication time was applied. The excluded studies were: studies with adult patients with NGT/NET who did not address adverse events; studies evaluating adverse events related to the use of gastrostomy, jejunostomy and/or ileostomy; and types of publication such as literature reviews, conference abstracts, and book chapters.

Two independent reviewers extracted information from the selected articles using a standardized form ${ }^{(15)}$ based on the PICO formula(14), also collecting data on: author(s), article date, country, type of research, sample definition, variable measuring and statistical analysis, main results and conclusions, as well as the level of evidence and recommendations by the authors. Thus, data from all of the selected studies were double extracted to check for consistency and any discrepancies which arose were discussed and resolved by the researchers, or were referred to the third reviewer for final decision.

The hierarchy of evidence classification proposed by Melnyk and Fineout-Overholt ${ }^{(14)}$ was used to evaluate the studies. This classification evaluates the level of evidence of each study and allows the researcher to analyze different types of methods.

Articles were analyzed and ranked according to the classification of AEs involving NGT/NET, as described by Blumenstein and colleagues $^{(9)}$ : Mechanical Adverse Events and Others.

The first major category, Mechanical Adverse Events, presented the following subcategories: respiratory complications; esophageal or pharyngeal complications; tube obstruction; intestinal perforation; intracranial perforation and; unplanned tube withdrawal. The second major category, called Others, included the following subcategories: pressure injury related to fixation and misconnection.

\section{Results}

Sixty-nine articles were considered to meet the criteria for inclusion in this integrative review. Figure 1 depicts the stages of the screening process undertaken to reach this selection in PRISMA format.

Figure 2 gives an overview of the included articles according to general characteristics: author, year, country, language and level of evidence. The papers included predominantly came from the USA $(n=24)$ and UK $(n=8)$, were published in $2010(n=6)$ and $2012(n=6)$, in English language $(n=67)$ and were classified with level of evidence VI $(n=67)$. Among all articles included in this review, death was reported in 16 and the main cause was the incorrect handling of the tube. The results are presented according to categories and subcategories and key aspects of each paper are presented, with the main findings.

\section{Category 1: Mechanical Adverse Events}

\section{Respiratory complications}

Forty-four articles ${ }^{(17-59)}$ were included in this subcategory. This subcategory contained the largest number of articles, showing that respiratory complications were the most common NGT/NETrelated group of AEs. In ten studies, death was reported due to incorrect insertion of the tube into the lungs $(20,29,31,35,44,48,51-52,56,58)$.

Respiratory AEs occurred mainly because of undue displacement of the NGT/NET to the respiratory tract and to the inconclusive results of the methods used to confirm the positioning of the distal tip of the tubes.

The most common respiratory $A E$ was pneumothorax, followed by pleural effusion and bronchoaspiration related to enteral nutrition. In most cases, a chest drain was required. The authors also reported drainage of a considerable volume of enteral feeding, ranging from $300 \mathrm{~mL}^{(58)}$ to $900 \mathrm{~mL}^{(43)}$.

There were reports of NGT/NET-associated pneumonia $(n=9)$, and in these cases the patient required antibiotic therapy. The results of this subcategory are summarized in Figure 3.

\section{Esophageal or pharyngeal complications}

In this subcategory, eight case reports ${ }^{(64-67)}$ were included; the authors described AEs related to the esophageal and/or pharyngeal insertion of the NGT/ NET. In two case reports, the event led to vocal cord paralysis and laryngeal harm ${ }^{(62,64)}$. 


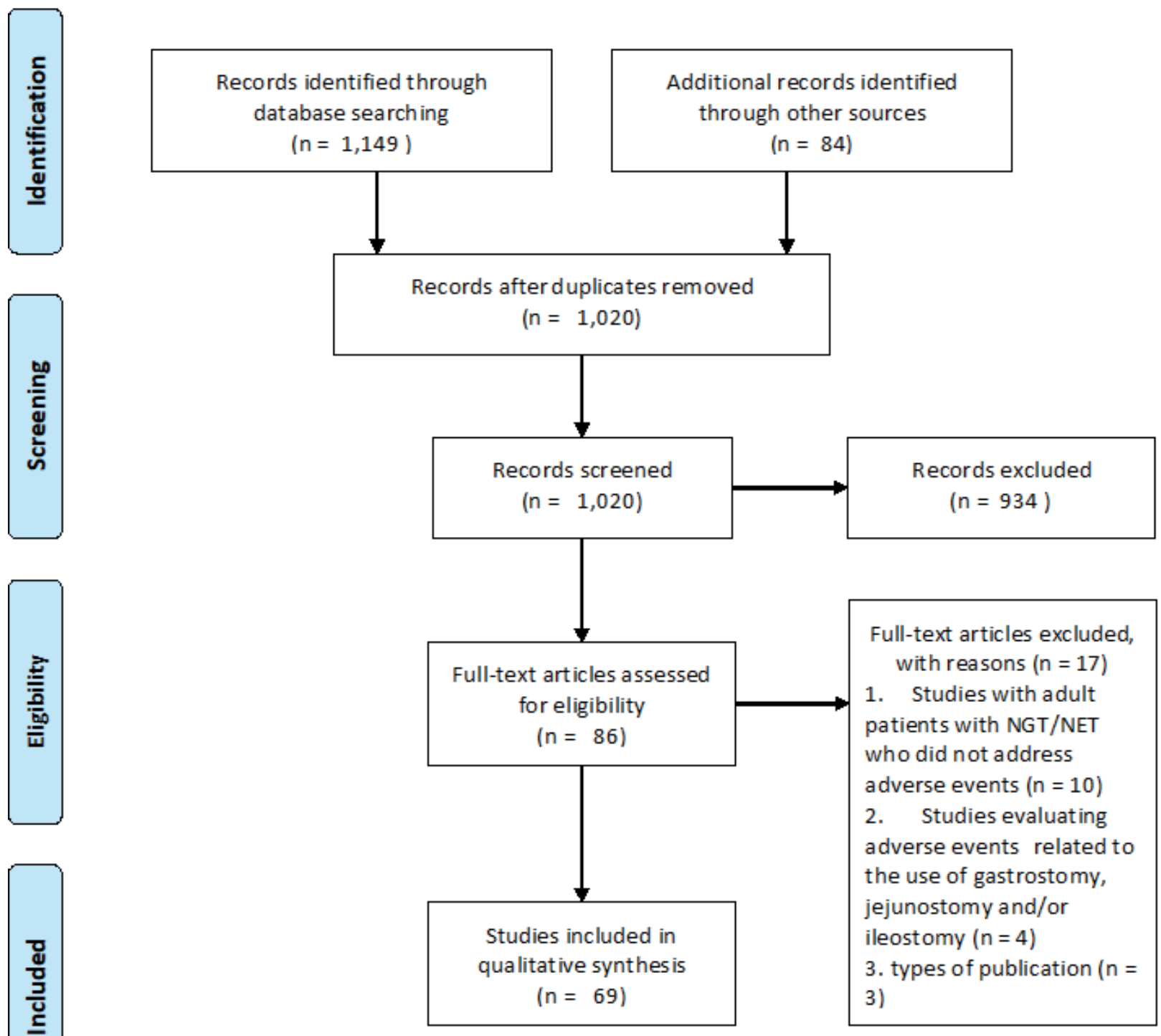

Figure 1 - Identification and selection flow of articles included in the integrative review, through database search. Ribeirão Preto, SP, Brazil, 2018(16)

\begin{tabular}{|c|c|c|c|c|c|}
\hline Article $\mathrm{n}^{\circ}$ & Author & Year & Country & Language & Level of Evidence \\
\hline \multicolumn{6}{|c|}{ Respiratory complications } \\
\hline 1 & Kearns, et al..$^{(17)}$ & 2000 & USA & English & II \\
\hline 2 & Attanasio, et al. ${ }^{(18)}$ & 2009 & Italy & English & $\mathrm{VI}$ \\
\hline 3 & Neumann, Delegge ${ }^{(19)}$ & 2002 & USA & English & II \\
\hline 4 & Rassias, et al. ${ }^{(20)}$ & 1998 & USA & English & $\mathrm{VI}$ \\
\hline 5 & Lin, et al. ${ }^{(21)}$ & 2008 & Taiwan & English & $\mathrm{VI}$ \\
\hline 6 & McWey, et al. ${ }^{(22)}$ & 1988 & USA & English & $\mathrm{VI}$ \\
\hline 7 & Bankier, et al. ${ }^{(23)}$ & 1997 & Austria & English & $\mathrm{VI}$ \\
\hline 8 & Marderstein, et al..$^{(24)}$ & 2004 & USA & English & $\mathrm{VI}$ \\
\hline 9 & de Aguilar-Nascimento, et al..$^{(10)}$ & 2007 & Brazil & English/Portuguese/Spanish & $\mathrm{VI}$ \\
\hline 10 & Metheny, et al. ${ }^{(25)}$ & 2011 & USA & English & $\mathrm{VI}$ \\
\hline 11 & Marco, et al.(26) & 2013 & Spain & English/Spanish & $\mathrm{VI}$ \\
\hline 12 & Sweatman, et al. ${ }^{(27)}$ & 1978 & USA & English & $\mathrm{VI}$ \\
\hline 13 & Vaughan ${ }^{(28)}$ & 1981 & UK & English & $\mathrm{VI}$ \\
\hline
\end{tabular}




\begin{tabular}{|c|c|c|c|c|c|}
\hline Article $n^{\circ}$ & Author & Year & Country & Language & Level of Evidence \\
\hline \multicolumn{6}{|c|}{ Respiratory complications } \\
\hline 14 & Balogh, et al. ${ }^{(29)}$ & 1983 & USA & English & VI \\
\hline 15 & McDanal, et al. ${ }^{(30)}$ & 1983 & USA & English & $\mathrm{VI}$ \\
\hline 16 & Schorlemmer, Battaglini $i^{(31)}$ & 1984 & USA & English & $\mathrm{VI}$ \\
\hline 17 & Harris, Filandrinos ${ }^{(32)}$ & 1993 & USA & English & $\mathrm{VI}$ \\
\hline 18 & Thomas, et al. ${ }^{(33)}$ & 1996 & USA & English & $\mathrm{VI}$ \\
\hline 19 & Kolbitsch, et al. ${ }^{(34)}$ & 1997 & Austria & English & $\mathrm{VI}$ \\
\hline 20 & Metheny, et al. ${ }^{(35)}$ & 1998 & USA & English & $\mathrm{VI}$ \\
\hline 21 & Winterholler, Erbguth ${ }^{(36)}$ & 2002 & Germany & English & $\mathrm{VI}$ \\
\hline 22 & Kannan, et al. ${ }^{(37)}$ & 1999 & UK & English & $\mathrm{VI}$ \\
\hline 23 & Howell, Shriver ${ }^{(38)}$ & 2005 & USA & English & $\mathrm{VI}$ \\
\hline 24 & O'Neil, Krishnananthan(39) & 2004 & Australia & English & $\mathrm{VI}$ \\
\hline 25 & Pillai, et al.(40) & 2005 & Canada & English & VI \\
\hline 26 & Kawati, Rubertsson ${ }^{(41)}$ & 2005 & Sweden & English & $\mathrm{VI}$ \\
\hline 27 & De Giacomo, et al. ${ }^{(42)}$ & 2006 & Italy & English & $\mathrm{VI}$ \\
\hline 28 & Haas, et al..$^{(43)}$ & 2006 & Netherlands & English & $\mathrm{VI}$ \\
\hline 29 & Freeberg, et al..$^{(44)}$ & 2010 & USA & English & $\mathrm{VI}$ \\
\hline 30 & Lemyze, Brown ${ }^{(45)}$ & 2009 & France & English & $\mathrm{VI}$ \\
\hline 31 & Lo, et al. ${ }^{(46)}$ & 2008 & USA & English & VI \\
\hline 32 & Wang, et al. ${ }^{(47)}$ & 2008 & Taiwan & English & VI \\
\hline 33 & Ishigami, et al. ${ }^{(48)}$ & 2009 & Japan & English & VI \\
\hline 34 & Takwoingi(49) & 2009 & UK & English & $\mathrm{VI}$ \\
\hline 35 & Chhavi, et al. ${ }^{(50)}$ & 2010 & India & English & $\mathrm{VI}$ \\
\hline 36 & Luo, et al. ${ }^{(51)}$ & 2011 & China & English & $\mathrm{VI}$ \\
\hline 37 & Shaikh, et al. ${ }^{(52)}$ & 2010 & Qatar & English & VI \\
\hline 38 & Sellers ${ }^{(53)}$ & 2012 & UK & English & $\mathrm{VI}$ \\
\hline 39 & Amirlak, et al. ${ }^{(54)}$ & 2012 & USA & English & VI \\
\hline 40 & Raut, et al.(55) & 2015 & India & English & $\mathrm{VI}$ \\
\hline 41 & Andresen, et al.(56) & 2016 & Denmark & English & $\mathrm{VI}$ \\
\hline 42 & Kao, et al. ${ }^{(57)}$ & 2012 & China & English & $\mathrm{VI}$ \\
\hline 43 & Leonard, et al. ${ }^{(58)}$ & 2012 & Ireland & English & $\mathrm{VI}$ \\
\hline 44 & Paul, et al.(59) & 2013 & USA & English & $\mathrm{VI}$ \\
\hline \multicolumn{6}{|c|}{ Esophageal or pharyngeal complications } \\
\hline 45 & James $^{(60)}$ & 1978 & UK & English & $\mathrm{VI}$ \\
\hline 46 & Duthorn, et al. ${ }^{(61)}$ & 1998 & Germany & English & $\mathrm{VI}$ \\
\hline 47 & Isozaki, et al.(62) & 2005 & Japan & English & $\mathrm{VI}$ \\
\hline 48 & Wu, et al. ${ }^{(63)}$ & 2006 & Taiwan & English & $\mathrm{VI}$ \\
\hline 49 & Campo, et al. ${ }^{(64)}$ & 2010 & Spain & Spanish & VI \\
\hline 50 & Sankar, et al. ${ }^{(65)}$ & 2012 & UK & English & VI \\
\hline 51 & Cereda, et al. ${ }^{(66)}$ & 2013 & Italy & English & $\mathrm{VI}$ \\
\hline 52 & Khasawneh, et al. ${ }^{(67)}$ & 2013 & USA & English & $\mathrm{VI}$ \\
\hline \multicolumn{6}{|c|}{ Tube obstruction } \\
\hline 53 & Attanasio, et al..$^{(18)}$ & 2009 & Italy & English & $\mathrm{VI}$ \\
\hline 54 & Cervo, et al. ${ }^{(68)}$ & 2014 & Brazil & English/Portuguese & $\mathrm{VI}$ \\
\hline 55 & Tawfic, et al. ${ }^{(69)}$ & 2012 & Oman & English & VI \\
\hline 56 & Van Dinter Jr, et al. ${ }^{(70)}$ & 2013 & USA & English & VI \\
\hline \multicolumn{6}{|c|}{ Intracranial perforation } \\
\hline 57 & Wyler, et al. ${ }^{(71)}$ & 1977 & USA & English & $\mathrm{VI}$ \\
\hline 58 & Glasser, et al. ${ }^{(72)}$ & 1990 & USA & English & VI \\
\hline
\end{tabular}

(the Figure 2 continue in the next page...) 


\begin{tabular}{|c|c|c|c|c|c|}
\hline Article $n^{\circ}$ & Author & Year & Country & Language & Level of Evidence \\
\hline \multicolumn{6}{|c|}{ Intracranial perforation } \\
\hline 59 & Freij, Mullett(73) & 1996 & UK & English & VI \\
\hline 60 & Ferreras, et al..$^{(74)}$ & 2000 & Spain & English & $\mathrm{VI}$ \\
\hline 61 & Genu, et al. ${ }^{(75)}$ & 2004 & Brazil & English & VI \\
\hline \multicolumn{6}{|c|}{ Unplanned Tube Removal } \\
\hline 62 & Carrion, et al. ${ }^{(76)}$ & 2000 & Spain & English & VI \\
\hline 63 & Nascimento, et al. ${ }^{(77)}$ & 2008 & Brazil & English/Portuguese and Spanish & $\mathrm{VI}$ \\
\hline \multicolumn{6}{|c|}{ Pressure Injury Related to Fixation } \\
\hline 64 & Güimil, et al. ${ }^{(78)}$ & 2010 & Spain & Spanish & VI \\
\hline \multicolumn{6}{|c|}{ Misconnections } \\
\hline 65 & Ghahremani, Gould ${ }^{(79)}$ & 1986 & USA & English & VI \\
\hline 66 & Takeshita, et al. ${ }^{\left({ }^{80)}\right.}$ & 2002 & Japan & English & VI \\
\hline 67 & Roberts, Swart ${ }^{(81)}$ & 2007 & UK & English & VI \\
\hline 68 & Thorat, Wang ${ }^{(82)}$ & 2008 & Singapore & English & $\mathrm{VI}$ \\
\hline 69 & Millin, Brooks ${ }^{(83)}$ & 2010 & USA & English & VI \\
\hline
\end{tabular}

Figure 2 - General characteristics of studies included in the review. Ribeirão Preto, SP, Brazil, 2018

\begin{tabular}{|c|c|c|c|}
\hline $\begin{array}{l}\text { Article } \\
\text { Number }\end{array}$ & Study Aim & Study Type & Main Results \\
\hline 1 & $\begin{array}{l}\text { To investigate the rate of VAP* and adequacy } \\
\text { of nutrient delivery with gastric vs small } \\
\text { intestinal feeding. }\end{array}$ & $\begin{array}{l}\text { Prospective, randomized, } \\
\text { controlled trial }\end{array}$ & $\begin{array}{l}\text { ICU' patients were observed for a period of } 15 \text { months. } \\
\text { All patients needed mechanical ventilation and enteral } \\
\text { nutrition. After tube insertion, all patients underwent } \\
\text { radiography to confirm tube placement. Aspiration or } \\
\text { VAP }^{*} \text { was confirmed between patients with } \mathrm{NGT}^{\ddagger} \text { and } \\
\mathrm{NET}^{\S} \text {, but the difference was not significant. }\end{array}$ \\
\hline 2 & $\begin{array}{l}\text { To describe the management of patients } \\
\text { treated with enteral nutrition and to identify } \\
\text { complications and mortality. }\end{array}$ & $\begin{array}{l}\text { Prospective observational } \\
\text { study }\end{array}$ & $\begin{array}{l}\text { From } 108 \text { patients included in the study, } 45 \text { used NET\$, } \\
62 \text { used gastrostomy and one patient had jejunostomy. } \\
\text { The following complications were observed: aspiration } \\
(15 \%) \text {; accidental removal }(62 \%) \text { and tube obstruction } \\
(11 \%) \text {. The mortality rate was } 23 \% \text { at one year and the } \\
\text { average survival was } 674 \text { days. }\end{array}$ \\
\hline 3 & $\begin{array}{l}\text { To compare the outcomes of } \mathrm{ICU}^{\dagger} \text { patients } \\
\text { fed through an } \mathrm{NGT}^{\ddagger} \text { vs. a nasal-small-bowel } \\
\text { tube including the time from tube placement to } \\
\text { feeding, time to reach goal rate, and adverse } \\
\text { events. }\end{array}$ & $\begin{array}{l}\text { Prospective randomized } \\
\text { study }\end{array}$ & $\begin{array}{l}\text { Sixty patients were randomized to receive gastric or } \\
\text { small-bowel tube feedings. Adverse outcomes included } \\
\text { witnessed aspiration, vomiting, and clinical/radiographic } \\
\text { evidence of aspiration. There was no difference in } \\
\text { aspiration events within groups. }\end{array}$ \\
\hline 4 & $\begin{array}{l}\text { To determine the type and incidence of } \\
\text { pulmonary complications associated with the } \\
\text { placement of narrow-bore enteral feeding } \\
\text { tubes. }\end{array}$ & $\begin{array}{l}\text { Prospective observational } \\
\text { study }\end{array}$ & $\begin{array}{l}740 \text { tubes were inserted and } 14 \text { cases }(2 \%) \text { of tube } \\
\text { misplacement to the trachea and bronchi were } \\
\text { identified. In all patients, auscultation was positive for } \\
\text { rustling sounds, but radiography identified the incorrect } \\
\text { positioning of the tip. Five patients suffered severe } \\
\text { complications (pneumothorax) and two died. }\end{array}$ \\
\hline 5 & $\begin{array}{l}\text { To investigate the prevalence rate and } \\
\text { influencing factors of pneumonia associated } \\
\text { with long-term feeding in special care units } \\
\text { for patients with persistent vegetative states } \\
\text { (PVS). }\end{array}$ & $\begin{array}{l}\text { Prospective observational } \\
\text { study }\end{array}$ & $\begin{array}{l}\text { Two hundred sixty subjects were chosen from three } \\
\text { hospital-based special care units for patients with } \\
\text { PVS and } 10 \text { nursing facilities for persons in PVS } \\
\text { in Taiwan. Data were collected through chart review and } \\
\text { observations. The factors associated with pneumonia } \\
\text { were: length of hospital stay and enteral nutrition. }\end{array}$ \\
\hline 6 & $\begin{array}{l}\text { To report the case of } 14 \text { patients who had } \\
\text { inadvertent tube misplacement, resulting in } \\
\text { complications that included pneumothorax, } \\
\text { empyema, mediastinitis, pneumonia, and } \\
\text { esophageal perforation. }\end{array}$ & $\begin{array}{l}\text { Retrospective observational } \\
\text { study }\end{array}$ & $\begin{array}{l}\text { Fourteen patients with a misplaced tube were selected } \\
\text { over a period of } 18 \text { months. Of the } 13 \text { patients who had } \\
\text { pulmonary complications, one had received enteral } \\
\text { nutrition before confirmation by X-ray. Complications } \\
\text { included pneumothorax, that required pleural drainage, } \\
\text { and esophageal perforation. }\end{array}$ \\
\hline 7 & $\begin{array}{l}\text { To illustrate the radiographic spectrum of the } \\
\text { intrabronchial malposition of gastric tubes and } \\
\text { subsequent complications, and to discuss the } \\
\text { role of radiography in the detection of such } \\
\text { malposition. }\end{array}$ & $\begin{array}{l}\text { Retrospective observational } \\
\text { study }\end{array}$ & $\begin{array}{l}\text { Over a period of } 11 \text { months, } 14 \text { cases of tube } \\
\text { misplacement were recorded in the tracheobronchial } \\
\text { tree. Of the } 14 \text { insertions, eight were performed blindly } \\
\text { at the bedside and six by laryngoscope. Nine tubes } \\
\text { were inserted in the right tracheobronchial tree and five } \\
\text { in the left. Four patients had pleural perforation, with } \\
\text { consequent pneumothorax and need for chest tube } \\
\text { insertion. Another four patients developed pneumonia. }\end{array}$ \\
\hline
\end{tabular}

(the Figure 3 continue in the next page...) 


\begin{tabular}{|c|c|c|c|}
\hline $\begin{array}{l}\text { Article } \\
\text { Number }\end{array}$ & Study Aim & Study Type & Main Results \\
\hline 8 & $\begin{array}{l}\text { To determine whether a specialized feeding } \\
\text { tube placement team had a beneficial effect } \\
\text { on procedure-related pneumothorax. }\end{array}$ & $\begin{array}{l}\text { Retrospective observational } \\
\text { study }\end{array}$ & $\begin{array}{l}\text { Over a three-year period, researchers analyzed reports } \\
\text { of NET§ displacement to the tracheobronchial tree. } \\
\text { Of the } 4,190 \text { patients included, } 683 \text { had respiratory } \\
\text { adverse events associated with the tube; of these, nine } \\
\text { suffered pneumothorax. }\end{array}$ \\
\hline 9 & $\begin{array}{l}\text { To investigate the use of radiographs, } \\
\text { fluoroscopy, feeding tubes, and complications } \\
\text { associated with blind feeding-tube placement. }\end{array}$ & $\begin{array}{l}\text { Retrospective observational } \\
\text { study }\end{array}$ & $\begin{array}{l}1,822 \mathrm{NET}^{\S} \text { were inserted in } 729 \text { patients. In } 23 \\
\text { patients, the tube was in the pulmonary position and } \\
\text { nine had pneumothorax. There was a significant } \\
\text { incidence of respiratory complications. Out of every } 100 \\
\text { patients, three presented inadvertent tube positioning. }\end{array}$ \\
\hline 10 & $\begin{array}{l}\text { To determine the extent to which aspiration } \\
\text { pneumonia are associated with feeding site } \\
\text { (controlling for the effects of severity of illness, } \\
\text { degree of head-of-bed elevation, level of } \\
\text { sedation, and use of gastric suction). }\end{array}$ & $\begin{array}{l}\text { Retrospective observational } \\
\text { study }\end{array}$ & $\begin{array}{l}\text { NGT }^{\ddagger} / \mathrm{NET}^{\S} \text { were inserted and the positioning } \\
\text { was confirmed by radiography. The prevalence of } \\
\text { pneumonia was significantly lower when the tube was } \\
\text { located in the intestine, especially in the jejunum. } \\
\text { This relationship remained when other variables were } \\
\text { analyzed, including: disease severity and sedation level. }\end{array}$ \\
\hline 11 & $\begin{array}{l}\text { To determine the relationship between enteral } \\
\text { nutrition feeding devices in patients admitted } \\
\text { to the Internal Medicine Departments and } \\
\text { the development of pulmonary complications } \\
\text { (bronchial aspiration and aspiration } \\
\text { pneumonia). }\end{array}$ & $\begin{array}{l}\text { Retrospective observational } \\
\text { study }\end{array}$ & $\begin{array}{l}2,767,259 \text { hospital discharges were observed; of these, } \\
0.92 \% \text { were from patients receiving enteral nutrition via } \\
\text { an enteral tube. These patients were found to be } 15 \\
\text { times more likely to have bronchoaspiration and the risk } \\
\text { of mortality was twice as high compared to patients who } \\
\text { did not receive an enteral nutrition. }\end{array}$ \\
\hline 12 & $\begin{array}{l}\text { To describe two cases of accidental invasion } \\
\text { of the trachea by esophageal tubes. }\end{array}$ & Case report & $\begin{array}{l}\text { Patient underwent abdominal surgery due to } \\
\text { dehiscence. Blind NGT is inserted for gastric } \\
\text { decompression. Upon arriving at the ICU }{ }^{\dagger} \text {, the patient } \\
\text { was restless and with increased respiratory rate. } \\
\text { Arterial blood gases revealed hypoxemia. Mechanical } \\
\text { ventilation had to be adjusted, but chest pectoral } \\
\text { expansions were not observed and a radiograph } \\
\text { showed that the tube was in the trachea. }\end{array}$ \\
\hline 13 & $\begin{array}{l}\text { To report a case in which passage of a narrow } \\
\text { bore nasogastric tube into and through the } \\
\text { right main bronchus and accidental soiling of } \\
\text { the lung parenchyma with Clinifeed. }\end{array}$ & Case report & $\begin{array}{l}\text { A 56-year-old man with head and neck cancer } \\
\text { underwent surgery to remove the tumor. After surgery, } \\
\text { NGT‡ was inserted and positioning was confirmed } \\
\text { by radiography. About } 400 \mathrm{~mL} \text { of enteral nutrition } \\
\text { was started. After the infusion, the patient presented } \\
\text { dyspnea, cyanosis and increased heart rate. A new } \\
\text { radiograph was performed and the tube was found to } \\
\text { be located in the right main bronchus. The tube was } \\
\text { removed and the patient required oxygen therapy. }\end{array}$ \\
\hline 14 & $\begin{array}{l}\text { To report three cases of pneumothorax } \\
\text { attributable to misplacement of a commercially } \\
\text { available mercury-weighted polyurethane } \\
\text { feeding tube stiffened by a steel wire stylet. }\end{array}$ & Case report & $\begin{array}{l}\text { A 73-year-old patient, after bypass surgery, had } \mathrm{NET}^{\S} \\
\text { inserted for enteral nutrition. Positioning was confirmed } \\
\text { by radiography, which revealed the presence of the } \\
\text { distal tip in the right main bronchus. The tube was } \\
\text { removed, however the patient had dyspnea and } \\
\text { auscultation of the right lung revealed diminished } \\
\text { sounds. A new radiograph was performed and } \\
\text { pneumothorax was confirmed. The patient required } \\
\text { thoracotomy to treat the adverse event and presented } \\
\text { hemorrhage, coma, need for mechanical ventilation } \\
\text { and, after seven weeks, he died. }\end{array}$ \\
\hline 15 & $\begin{array}{l}\text { To describe a case of massive intrapulmonary } \\
\text { hemorrhage following the insertion of an NGT } \\
\text { into the tracheobronchial tree in an awake, } \\
\text { alert, and cooperative patient. }\end{array}$ & Case report & $\begin{array}{l}\text { An 82-year-old man suffered a car accident and was } \\
\text { hospitalized after clavicle resection surgery. He was } \\
\text { intubated with unstable vital signs and pulmonary } \\
\text { edema. NGT‡ was required for gastric decompression. } \\
\text { Initially, the tube was inserted uneventfully, but after } \\
\text { a few minutes, blood was observed through the tube } \\
\text { and vital signs decreased. Large amounts of blood } \\
\text { returned through the tube. Radiography was performed } \\
\text { and it was verified that the tube had crossed the left } \\
\text { pleura. By laryngoscopy, the NGT‡ was removed and } \\
\text { a left chest tube was required. About } 1,500 \text { ml of blood } \\
\text { was drained. The patient continued with mechanical } \\
\text { ventilation and required gastrostomy. Ninety days later, } \\
\text { the patient was discharged home. }\end{array}$ \\
\hline 16 & $\begin{array}{l}\text { To report three cases of a potentially life- } \\
\text { threatening complication associated with } \\
\text { NGT‡/NET§. }\end{array}$ & Case report & $\begin{array}{l}\text { In two cases, the patients were tracheostomized and } \\
\text { required a feeding tube, but the tubes were accidentally } \\
\text { removed. During insertion of the new tube, patients } \\
\text { had respiratory distress and hypoxemia. The tubes } \\
\text { were located in the pleura and pneumothorax was } \\
\text { diagnosed. One patient died. The third case involved a } \\
\text { patient already using a feeding tube, but it was removed } \\
\text { accidentally, requiring a new insertion. The patient had } \\
\text { a productive cough and the tube was removed. X-ray } \\
\text { showed infiltration in the right lung median lobe and } \\
\text { another tube was inserted. }\end{array}$ \\
\hline
\end{tabular}

(the Figure 3 continue in the next page...) 


\begin{tabular}{|c|c|c|c|}
\hline $\begin{array}{c}\text { Article } \\
\text { Number }\end{array}$ & Study Aim & Study Type & Main Results \\
\hline 17 & $\begin{array}{l}\text { To report a case of accidental activated } \\
\text { charcoal instillation into the lung of a } \\
30 \text {-year-old man being managed for a cyclic } \\
\text { antidepressant overdose. }\end{array}$ & Case report & $\begin{array}{l}\mathrm{NGT}^{\ddagger} \text { was inserted for activated carbon gastric lavage. } \\
\text { Then, arterial puncture was performed and blood gases } \\
\text { were within the normal range. The tube needed to be } \\
\text { replaced without incident. } 15 \mathrm{~mL} \text { of activated charcoal } \\
\text { were administered. The patient experienced a sudden } \\
\text { change in oxygen saturation and vital signs though. } \\
\text { Radiography revealed that the tube was in the right } \\
\text { main bronchus and the patient was transferred to } \\
\text { the ICU }{ }^{+} \text {with the vital signs altered. He needed to be } \\
\text { intubated and progressed to pneumonia. }\end{array}$ \\
\hline 18 & $\begin{array}{l}\text { To report an instance of the intrapleural } \\
\text { administration of charcoal due to penetration } \\
\text { of the pleura by a transbronchial nasogastric } \\
\text { tube. }\end{array}$ & Case report & 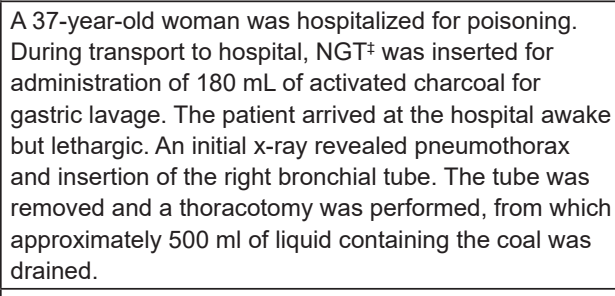 \\
\hline 19 & $\begin{array}{l}\text { To report a case of pneumothorax caused } \\
\text { by the improper placement of an NGT in a } \\
\text { tracheostomized patient after bilateral lung } \\
\text { transplantation. }\end{array}$ & Case report & $\begin{array}{l}\text { A 50-year-old man was admitted for lung transplant } \\
\text { surgery. Due to postoperative complications, } \\
\text { mechanical ventilation and tracheostomy were } \\
\text { required. A NET§ was also inserted. There were three } \\
\text { attempts and positioning was confirmed by auscultatory } \\
\text { method. There was aspiration of yellowish residue. } \\
\text { No radiography was performed because a chest } \\
\text { tomography was scheduled. According to the exam, the } \\
\text { tube was positioned in the lung and rupture of the right } \\
\text { lower lobe pleura was identified. The tube was removed } \\
\text { and a thoracotomy was performed. }\end{array}$ \\
\hline 20 & $\begin{array}{l}\text { To describe potentially disastrous outcomes } \\
\text { associated with failure to determine when } \\
\text { nasally inserted feeding tubes are improperly } \\
\text { positioned. }\end{array}$ & Case report & $\begin{array}{l}\text { Two cases were presented. In the first, uneventful NGT } \\
\text { was inserted in a } 70 \text {-year-old patient with stroke and } \\
\text { dysphagia. Placement was confirmed by two nurses } \\
\text { using the auscultatory method; enteral nutrition was } \\
\text { administered. After a few hours, the nurse observed } \\
\text { that the patient was dyspneic and cyanotic and was } \\
\text { transferred to the ICU+. The tube was found in the lung } \\
\text { and the patient died of respiratory complications. In } \\
\text { the second case, after } 13 \text { days of hospitalization, the } \\
\text { patient required a new tube due to accidental removal. } \\
\text { The confirmation method was performed by placing the } \\
\text { distal tip of the tube in water. No blisters were observed } \\
\text { and the enteral nutrition was started. After } 3 \text { hours, the } \\
\text { patient had respiratory distress; radiography revealed } \\
\text { that the tube was in the left main bronchus of the lung. } \\
\text { Thoracic drainage was started to remove the fluid. }\end{array}$ \\
\hline 21 & $\begin{array}{l}\text { To report an instance of inadvertent placement } \\
\text { of a standard NGT" into the left pleural } \\
\text { space in a patient with right parietotemporal } \\
\text { intracerebral hemorrhage and severe } \\
\text { hemineglect on the left side. }\end{array}$ & Case report & $\begin{array}{l}\text { A 69-year-old patient admitted for stroke was drowsy } \\
\text { but able to communicate. NGT }{ }^{\ddagger} \text { was inserted for } \\
\text { medication and feeding. There were no complications } \\
\text { during insertion, and tube positioning was confirmed } \\
\text { by abdominal auscultation. } 100 \mathrm{~mL} \text { of enteral nutrition } \\
\text { were administered. After a few minutes, the patient had } \\
\text { severe dyspnea. Radiography confirmed the positioning } \\
\text { of the tube in the left bronchus, pleural effusion and } \\
\text { pneumothorax. The tube was removed and patient } \\
\text { intubation was required, followed by bronchoscopy and } \\
\text { thoracotomy. In addition, the patient had pneumonia. }\end{array}$ \\
\hline 22 & $\begin{array}{l}\text { To report a case where the patient } \\
\text { developed both tension pneumothorax and } \\
\text { pneumomediastinum when an NGT } \mathrm{N}^{\ddagger} \text { was } \\
\text { inserted. }\end{array}$ & Case report & $\begin{array}{l}\text { A } 77 \text {-year-old woman was admitted to the ICU } \mathrm{IU}^{\dagger} \text { due } \\
\text { to diabetic acidosis and subsequent left lower limb } \\
\text { amputation. She required mechanical ventilation and, } \\
\text { after three days, she was extubated. Six hours later, } \\
\text { an attempt was made to insert an NGT", but there was } \\
\text { difficulty during the procedure and the patient required } \\
\text { oxygen supplementation. A new attempt was made, but } \\
\text { without success. It was decided to insert the tube with } \\
\text { the aid of lubricated biopsy forceps to act as a guide. } \\
\text { The positioning of the tube was confirmed by aspiration } \\
\text { of residue, but without success. Then the auscultation } \\
\text { test was performed, and the result was negative. After } \\
\text { a few minutes, the patient presented a reduction in } \\
\text { oxygen saturation to } 60 \% \text {, increased blood pressure } \\
\text { and tachycardia. The tube was removed and ventilatory } \\
\text { support was provided. Radiography revealed right } \\
\text { pneumothorax and the patient needed to be intubated } \\
\text { again. A chest drain was also required. }\end{array}$ \\
\hline
\end{tabular}




\begin{tabular}{|c|c|c|c|}
\hline $\begin{array}{l}\text { Article } \\
\text { Number }\end{array}$ & Study Aim & Study Type & Main Results \\
\hline 23 & $\begin{array}{l}\text { To report a case of hydropneumothorax } \\
\text { caused by inadvertent placement of a Dobhoff } \\
\text { tube. }\end{array}$ & Case report & $\begin{array}{l}\text { A 78-year-old woman was hospitalized due to maxillary } \\
\text { carcinoma. She needed a NET§ for enteral nutrition. } \\
\text { After tube insertion, the patient presented changes in } \\
\text { vital signs (increased heart rate, increased respiratory } \\
\text { rate and increased blood pressure). Arterial blood gas } \\
\text { confirmed hypoxemia in ambient air and radiography } \\
\text { revealed hydropneumothorax. The tube was inserted } \\
\text { into the right lung. Enteral nutrition was started without } \\
\text { confirming the tube positioning. Thoracoscopy was } \\
\text { required to resolve the hydropneumothorax. }\end{array}$ \\
\hline 24 & $\begin{array}{l}\text { To report six cases of intrapleural NGT } \\
\text { insertion. }\end{array}$ & Case report & $\begin{array}{l}\text { Six cases of elderly in the } \mathrm{ICU}^{\dagger} \text { with central nervous } \\
\text { system dysfunction were reported. Of these, four } \\
\text { were intubated and all had an NGT }{ }^{\ddagger} \text { inserted. The } \\
\text { positioning of the tube was confirmed by radiography. In } \\
\text { five patients, the tube was inserted into the right main } \\
\text { bronchus and in one patient, the tube was inserted } \\
\text { into the left bronchus. In five patients, the tube was } \\
\text { immediately repositioned and, in one case, the patient } \\
\text { received the enteral nutrition through a misplaced tube. } \\
\text { Four elderly had pneumothorax. }\end{array}$ \\
\hline 25 & $\begin{array}{l}\text { To analyze the insertion of an } \mathrm{NGT}^{\ddagger} \text {, though } \\
\text { a common clinical procedure, and explore } \\
\text { means to improve its safety. }\end{array}$ & Case report & $\begin{array}{l}\text { An } 80 \text {-year-old patient with previous bypass surgery } \\
\text { required mechanical ventilation and remained in the } \\
\mathrm{ICU}^{\dagger} \text { for a period of time. Patient required an } \mathrm{NGT}^{\ddagger} \text { for } \\
\text { enteral nutrition and a radiograph was performed to } \\
\text { confirm its positioning. The NGT }{ }^{\ddagger} \text { was located in the } \\
\text { right pleural space. The tube was removed immediately } \\
\text { and after two hours, a new radiograph confirmed } \\
\text { pneumothorax. }\end{array}$ \\
\hline 26 & $\begin{array}{l}\text { To report three cases of nasopulmonary } \\
\text { misplacement of the feeding tube in an } \mathrm{ICU}^{\dagger} \text {. }\end{array}$ & Case report & 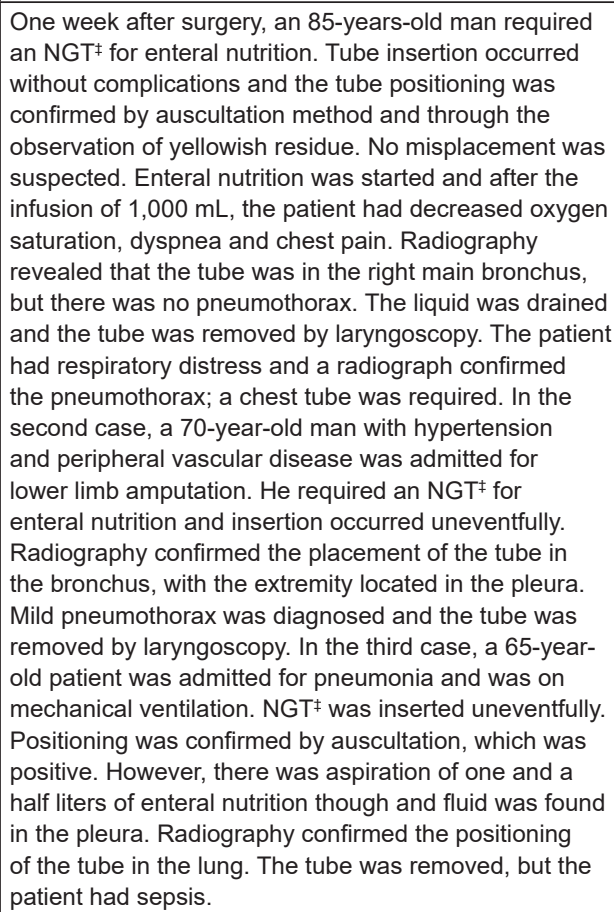 \\
\hline 27 & $\begin{array}{l}\text { To describe the bronchoscopic control of a } \\
\text { significant and prolonged air-leakage, because } \\
\text { of malposition of narrow-bore feeding tube, by } \\
\text { placing a newly designed airway prosthesis } \\
\text { with one-way valve into the corresponding } \\
\text { segmental bronchus responsible for air- } \\
\text { leakage source. }\end{array}$ & Case report & $\begin{array}{l}\text { A 38-year-old woman diagnosed with bilateral } \\
\text { pneumonia and respiratory failure was mechanically } \\
\text { ventilated. An NGT } \mathrm{NG}^{\ddagger} \text { was inserted with the aid of } \\
\text { an electromagnetic device. After a few hours, low } \\
\text { saturation, tachycardia and hypotension occurred. } \\
\text { Radiography revealed pneumothorax and a chest tube } \\
\text { was inserted. The tomography showed that the tube } \\
\text { was inserted into the tracheobronchial tree and that } \\
\text { there was air leakage due to mechanical ventilation. } \\
\text { The problem was solved by means of a valve, which } \\
\text { was removed with subsequent extubation of the patient. }\end{array}$ \\
\hline 28 & $\begin{array}{l}\text { To report a serious complication of blind NGT } \\
\text { insertion in a } 65 \text {-years-old female patient, } \\
\text { which was overlooked and caused severe } \\
\text { respiratory failure. }\end{array}$ & Case report & $\begin{array}{l}\text { An NGT‡ was inserted and its positioning was confirmed } \\
\text { by abdominal auscultation and radiography. On the } \\
\text { following day, the patient presented cough, tachypnea } \\
\text { and fever, with pleural effusion and collapse of the right } \\
\text { lung lobe. Laryngoscopy confirmed the endotracheal } \\
\text { positioning of the tube. This was removed without } \\
\text { resistance. A radiograph revealed right pneumothorax } \\
\text { and a thoracotomy with } 900 \mathrm{~mL} \text { drainage of the enteral } \\
\text { nutrition was required. }\end{array}$ \\
\hline
\end{tabular}




\begin{tabular}{|c|c|c|c|}
\hline $\begin{array}{l}\text { Article } \\
\text { Number }\end{array}$ & Study Aim & Study Type & Main Results \\
\hline 29 & $\begin{array}{l}\text { To report } 3 \text { cases of severe } \\
\text { pleuropulmonary complications after } \\
\text { routine bedside placement of a narrow- } \\
\text { bore enteral feeding tube. }\end{array}$ & Case report & $\begin{array}{l}\text { Cases of severe pulmonary complications were } \\
\text { reported after NET\$ insertion. In two cases, the } \\
\text { radiograph revealed a tube positioned in the lung, } \\
\text { causing pneumothorax that needed to be drained. The } \\
\text { third case dealt with a patient on mechanical ventilation } \\
\text { whose tube was inserted into the lung with consequent } \\
\text { pneumothorax. The patient died due to cerebral } \\
\text { ischemia. }\end{array}$ \\
\hline 30 & $\begin{array}{l}\text { To report a case of an } \mathrm{NGT}^{*} \text { inadvertently } \\
\text { positioned in the respiratory tract. }\end{array}$ & Case report & $\begin{array}{l}\text { A } 76 \text {-year-old man was admitted with a diagnosis } \\
\text { of stroke. He needed a feeding tube due to risk of } \\
\text { aspiration. The procedure was performed uneventfully } \\
\text { and the patient had no complaints. The physician } \\
\text { confirmed the positioning by the auscultation method } \\
\text { and the enteral nutrition was released. After a few } \\
\text { hours, the patient was transferred to the ICU due to } \\
\text { acute respiratory failure. Radiographic examination } \\
\text { revealed the placement of the tube in the lower lobe of } \\
\text { the right lung. }\end{array}$ \\
\hline 31 & $\begin{array}{l}\text { To report a case of a misplaced NGT into the } \\
\text { pulmonary pleura. }\end{array}$ & Case report & $\begin{array}{l}\text { A 50-year-old man was admitted to the emergency } \\
\text { department. On the fourth day of hospitalization, an } \\
\text { NGT‡ was inserted and confirmed by radiography. } 750 \\
\text { mL of enteral nutrition were administered. The following } \\
\text { day, the patient had shortness of breath and pleural } \\
\text { effusion and pneumothorax were confirmed. The patient } \\
\text { underwent thoracotomy and antibiotic therapy and he } \\
\text { was discharged after } 33 \text { days. }\end{array}$ \\
\hline 32 & $\begin{array}{l}\text { To report a case of inadvertent NGT" insertion } \\
\text { into the right lower lobe bronchus. }\end{array}$ & Case report & $\begin{array}{l}\text { A 79-year-old man with Chronic Obstructive Pulmonary } \\
\text { Disease was admitted to the ICU }{ }^{\dagger} \text { and underwent } \\
\text { mechanical ventilation. Subsequently, tracheostomy } \\
\text { was performed. The patient was using an NET§ for } \\
\text { enteral nutrition. A new tube was required and it was } \\
\text { blindly inserted by the nurse in the ward. The position } \\
\text { of the tube was confirmed by auscultation. Then, } \\
\text { enteral nutrition was started. During the night, the nurse } \\
\text { verified that the tube was wrapped around the patient's } \\
\text { mouth and the tube was inserted again. Immediately } \\
\text { after the enteral nutrition was administered, the patient } \\
\text { coughed, and after several unsuccessful attempts, the } \\
\text { nurse opened the tube and drained it. The following } \\
\text { morning, a small amount of liquid was observed through } \\
\text { the tracheostomy tube. An x-ray revealed that the tube } \\
\text { passed through the tracheostomy balloon and into the } \\
\text { right bronchus. The patient was tachypneic and did not } \\
\text { respond to external stimuli and he was transferred back } \\
\text { to the ICUt. }\end{array}$ \\
\hline 33 & $\begin{array}{l}\text { To report a case of NGT inserted into the } \\
\text { pleural cavity passing the trachea and left } \\
\text { bronchi. }\end{array}$ & Case report & 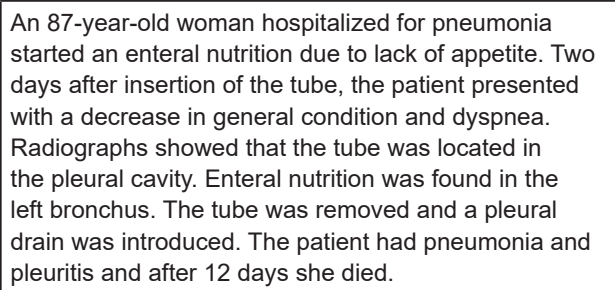 \\
\hline 34 & $\begin{array}{l}\text { To report an unusual case of malpositioning of } \\
\text { a fine bore NGT } \text { into both main bronchi in a } \\
\text { patient that was awake. }\end{array}$ & Case report & $\begin{array}{l}\text { A 71-year-old woman with hypopharyngeal carcinoma } \\
\text { required an NGT } \text { after chemotherapy treatment. The } \\
\text { tube was obstructed and a new one was required. There } \\
\text { was no resistance during insertion, however the patient } \\
\text { presented cough. The tube positioning was confirmed } \\
\text { by auscultation. Next, a radiograph was performed } \\
\text { and revealed that the tube was coiled in both bronchi. } \\
\text { The tube was inserted into the left bronchus, bent and } \\
\text { migrated to the right bronchus, and was therefore found } \\
\text { in both major bronchi. Gastrostomy was required due to } \\
\text { esophageal stenosis. }\end{array}$ \\
\hline 35 & $\begin{array}{l}\text { To report a case of accidental tracheal } \\
\text { intubation of feeding tube in an intubated } \\
\text { patient who developed respiratory distress a } \\
\text { few minutes after test feed administration. }\end{array}$ & Case report & $\begin{array}{l}\text { A 32-year-old man suffered a traffic accident with chest } \\
\text { trauma, diaphragmatic rupture and fracture of left } \\
\text { leg bones. He was operated and referred to the ICU } \\
\text { and an NGT } \\
\text { of the tube occurred uneventffully and its position } \\
\text { was confirmed by auscultation. } 100 \mathrm{ml} \text { of water was } \\
\text { administered. After a few minutes, the patient presented } \\
\text { respiratory disorder and decreased oxygen saturation, } \\
\text { requiring mechanical ventilation. The positioning of } \\
\text { the tube was verified again by laryngoscopy, which } \\
\text { confirmed the positioning of the distal tip in the trachea. }\end{array}$ \\
\hline
\end{tabular}

(the Figure 3 continue in the next page...) 


\begin{tabular}{|c|c|c|c|}
\hline $\begin{array}{l}\text { Article } \\
\text { Number }\end{array}$ & Study Aim & Study Type & Main Results \\
\hline 36 & $\begin{array}{l}\text { To report six cases of tracheobronchial } \\
\text { malposition of fine bore feeding tube in } \\
\text { patients with mechanical ventilation. }\end{array}$ & Case report & $\begin{array}{l}\text { Patient had cough and tachycardia during NGT } \text { NG }^{\ddagger} \\
\text { insertion and bronchoscopy confirmed inadequate } \\
\text { positioning of the tube. In four patients, NGT } \text { INET }^{\S} \\
\text { insertion was performed without complications and the } \\
\text { test used to confirm the positioning was auscultation. } \\
\text { Subsequently, bronchoscopy and radiography were } \\
\text { performed to confirm possible pneumonia. Tests } \\
\text { confirmed inadvertent placement of the tube. The sixth } \\
\text { patient did not present cough during the insertion of the } \\
\text { tube and the epigastric auscultation test was performed } \\
\text { to confirm the positioning. A chest computerized } \\
\text { tomography confirmed the placement of the tube in the } \\
\text { tracheobronchial region. The patient died after } 12 \text { days } \\
\text { due to the blood infection. }\end{array}$ \\
\hline 37 & $\begin{array}{l}\text { To report three cases of enteral feeding tube } \\
\text { malpositioned into the respiratory system. }\end{array}$ & Case report & $\begin{array}{l}\text { In the first case, a mechanically ventilated postoperative } \\
\text { patient required an NGT" for gastric decompression. } \\
\text { The spontaneous drainage bottle was filled with } \\
\text { respiratory tidal volume. Radiography indicated that the } \\
\text { NGT }^{\ddagger} \text { was positioned in the left main bronchus. New } \\
\text { NGT }^{\ddagger} \text { was inserted by laryngoscopy. } \\
\text { The second patient had diabetic foot, multiple organ } \\
\text { dysfunction and sepsis and was admitted to the } \\
\text { ICU after limb amputation. She was on mechanical } \\
\text { ventilation and required a tracheostomy tube. She } \\
\text { remained with enteral feeding via NGT. After five weeks } \\
\text { with the tube, it needed to be replaced as it migrated to } \\
\text { the left main bronchus. A new tube was inserted and the } \\
\text { positioning was confirmed by radiography. The patient } \\
\text { progressed to septic shock and died after } 76 \text { days of } \\
\text { hospitalization. } \\
\text { The third patient had spontaneous intraventricular } \\
\text { bleeding and was admitted to the ICU with respiratory } \\
\text { failure. NGT }{ }^{\ddagger} \text { was inserted and positioning was } \\
\text { confirmed by radiography, which indicated the location } \\
\text { of the distal tip in the right bronchus. The tube was } \\
\text { immediately removed and another tube was inserted. } \\
\text { The positioning of the new tube was confirmed by } \\
\text { radiography. }\end{array}$ \\
\hline 38 & $\begin{array}{l}\text { To report a case describing false-positive } \\
\text { NGT placement confirmation tests in a } \\
\text { patient with head and neck cancer, who was } \\
\text { administered feed into lung parenchyma with } \\
\text { significant morbidity. }\end{array}$ & Case report & $\begin{array}{l}\text { A 54-year-old man with head and neck cancer was } \\
\text { admitted to the ward for nutritional support. Blind NGT } \\
\text { was inserted and positioning was confirmed by } \mathrm{pH} \\
\text { test. Next, the administration of enteral nutrition began. } \\
\text { The next day, the patient complained of nausea and } \\
77 \% \text { oxygen saturation in room air was observed. } \\
\text { Radiography was performed and the positioning of } \\
\text { the tube in the lung was confirmed. } 540 \mathrm{~mL} \text { of enteral } \\
\text { nutrition were drained from the lung and antibiotic } \\
\text { therapy was started. }\end{array}$ \\
\hline 39 & $\begin{array}{l}\text { To report two cases of pneumothorax following } \\
\text { small-bore feeding tube insertion into the } \\
\text { pleural cavity, resulting in pneumothorax. }\end{array}$ & Case report & $\begin{array}{l}\text { In the first case, NET§ was inserted and the patient } \\
\text { showed no signs of respiratory distress during insertion. } \\
\text { However, the x-ray confirmed the position of the } \\
\text { distal tip in the right main bronchus and consequent } \\
\text { pneumothorax. In the second case, an NET§ was } \\
\text { inserted in a patient on mechanical ventilation. During } \\
\text { insertion, there was no change in oxygen saturation and } \\
\text { the cuff remained inflated. However, the x-ray confirmed } \\
\text { the placement of the tube in the left lung. Patient } \\
\text { presented a decrease in saturation and blood pressure, } \\
\text { a hypertensive pneumothorax and a chest tube were } \\
\text { inserted. }\end{array}$ \\
\hline 40 & To report a case of malposition of an NGT & Case report & $\begin{array}{l}\text { A 70-year-old man with Chronic Obstructive Pulmonary } \\
\text { Disease was admitted for bypass surgery. After surgery, } \\
\text { there was a need to insert an NGT', which occurred } \\
\text { uneventfully. Positioning of the distal tip was confirmed } \\
\text { by auscultatory method, but in the ICU†, radiography } \\
\text { was performed before beginning the administration of } \\
\text { enteral nutrition and medications. X-ray confirmed the } \\
\text { placement of the tube in the right main bronchus. }\end{array}$ \\
\hline 41 & $\begin{array}{l}\text { To report the first documented fatality from } \\
\text { pressure pneumothorax following NGT } \\
\text { withdrawal. }\end{array}$ & Case report & $\begin{array}{l}\text { An 84-year-old woman with dysphagia and risk of } \\
\text { aspiration required a feeding tube. After insertion, the } \\
\text { patient had difficulty breathing and the x-ray revealed } \\
\text { positioning of the tube in the lung. The tube was } \\
\text { removed, but the patient died after one hour. Necropsy } \\
\text { showed cause of death: pneumothorax after tube } \\
\text { withdrawal. }\end{array}$ \\
\hline
\end{tabular}

(the Figure 3 continue in the next page...) 


\begin{tabular}{|c|c|c|c|}
\hline $\begin{array}{c}\text { Article } \\
\text { Number }\end{array}$ & Study Aim & Study Type & Main Results \\
\hline 42 & $\begin{array}{l}\text { To report a case of severe acute respiratory } \\
\text { distress syndrome induced by bronchopleural } \\
\text { fistula due to malposition of NGT }\end{array}$ & Case report & 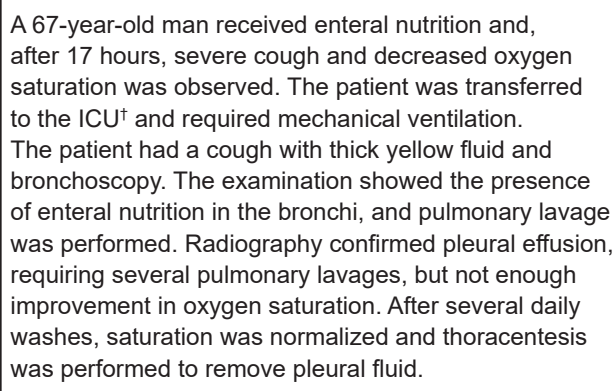 \\
\hline 43 & $\begin{array}{l}\text { To report two cases of NGT }{ }^{\ddagger} \text { placement } \\
\text { which resulted in significant morbidity from a } \\
\text { common procedure. }\end{array}$ & Case report & $\begin{array}{l}\text { An 88-year-old woman, admitted by stroke, required } \\
\text { an enteral feeding tube. Two days after the insertion, } \\
\text { it needed to be replaced with another one. Positioning } \\
\text { was confirmed by the epigastric auscultation } \\
\text { method. Soon after, the patient showed agitation and } \\
\text { radiography confirmed the positioning of the tube in } \\
\text { the right main bronchus and pneumothorax. A chest } \\
\text { tube was introduced, but the patient progressed to } \\
\text { pneumonia. Subsequently, the medical team chose to } \\
\text { feed her via gastrostomy. } \\
\text { A } 73 \text {-year-old patient was admitted to the geriatric } \\
\text { ward because of circulatory complications. NGT }{ }^{\ddagger} \text { was } \\
\text { inserted for feeding and the position was confirmed by } \\
\text { radiography. Enteral nutrition was then released. After } \\
\text { five hours, the patient presented respiratory impairment. } \\
\text { A new x-ray confirmed that the tube was positioned } \\
\text { in the lung and that there was about } 300 \text { mL of liquid, } \\
\text { as well as abscess and pleural effusion. The fluid was } \\
\text { drained and the patient was treated with antibiotics. This } \\
\text { adverse event resulted in increased length of hospital } \\
\text { stay and death after six months. }\end{array}$ \\
\hline 44 & $\begin{array}{l}\text { To report a case of a right-sided malpositioned } \\
\mathrm{NGT}^{\ddagger} \text { which caused a pneumothorax only on } \\
\text { its removal. }\end{array}$ & Case report & $\begin{array}{l}\text { An } 85 \text {-year-old female with advanced dementia } \\
\text { was admitted due to severe dehydration caused by } \\
\text { poor appetite. Intravenous solutions were infused } \\
\text { and NGT } \text { was inserted for enteral feeding. Initially, } \text { the procedure was uneventful, but a cough was } \\
\text { observed. A radiograph was taken and it showed that } \\
\text { the tube was positioned in the right main bronchus. } \\
\text { The NGT } \text { was removed. Then, the patient evolved to } \text { thoracic discomfort and the second radiograph found } \\
\text { pneumothorax. The patient required supplemental } \\
\text { oxygen for two days. }\end{array}$ \\
\hline
\end{tabular}

${ }^{*} \mathrm{VAP}=$ Ventilator-associated pneumonia; ${ }^{+} \mathrm{ICU}=$ Intensive Care Unit; ${ }^{\mathrm{N}} \mathrm{NGT}=$ Nasogastric tube; ${ }^{\mathrm{N}} \mathrm{NET}=$ Nasoenteric tube

Figure 3 - Key features of the subcategory respiratory complications described in included articles. Ribeirão Preto, SP, Brazil, 2018

In one article, the authors described the case of a patient with perforation of the nasopharynx, anterior carotid artery and internal jugular vein after insertion of the tube because its distal tip crossed the parotid gland(67). Death was reported in two articles due to nasogastric tube syndrome ${ }^{(62)}$ and fatal massive hemorrhage caused by nasogastric tube misplacement ${ }^{(63)}$. These results are summarized in Figure 4.

\section{Tube obstruction}

In this subcategory, three articles were included and the observational studies pointed out that the main $\mathrm{AE}$ was tube obstruction. In one study ${ }^{(18)}$, the rate of tube obstruction was $11 \%$, whereas in another ${ }^{(68)}$ the rate was $21 \%$. In the case report, medication administration was needed to unclog the tube and the cause of the obstruction was the concomitant administration of enteral feeding and medications. The drug-nutrient interaction resulted in bezoar formation that obstructed the tube lumen ${ }^{(69)}$ (Figure 4).

\section{Intestinal perforation}

This subcategory included one case report(70). The authors described the case of a patient who died due to intestinal perforation after NET insertion. At necropsy, intestinal perforation was found in the bypass region caused by insertion of the last tube.

Intracranial perforation

In this subcategory, five case reports ${ }^{(71-75)}$ were included and the majority were accident victims with a resulting skull base fracture. Due to the rupture of the cribriform plaque, the NGT penetrated the intracranial region ${ }^{(71,74-75)}$. Death was reported in two articles ${ }^{(71,73)}$. The result was summarized in Figure 4. 


\section{Unplanned tube removal}

In this subcategory, two articles were grouped(76-77). In one, the authors calculated the rate of tubes removed accidentally ${ }^{(76)}$. In the other article, the authors performed a retrospective study and found that the most frequent $A E$ was the unplanned tube removal(77). The most common cause was removal by the patient(76-77) (Figure 4).

\section{Category 2: Others}

\section{Pressure injury related to fixation}

In this subcategory, a prospective observational study ${ }^{(78)}$ was included. The study showed that the incidence of NGT/NET-related pressure injury was $25.2 \%$, related mainly to tube fixation (Figure 5).

\section{Misconnections}

We included five articles(79-83) in this subcategory that portrayed the AE caused by misconnection. In one article, the authors reported the case of a patient with NGT and who presented $8 \%$ of burned body surface due to the extravasation of gastric juice after accidental tube disconnection ${ }^{(82)}$. In two studies, the patients used a central venous catheter and an NGT/NET. The nurse inadvertently connected the enteral cable set to the central venous catheter. One patient received enteral feeding in the bloodstream and died( ${ }^{(80)}$; in another study, the patient received oral medications in the bloodstream, requiring orotracheal intubation. The patient was discharged after eight weeks ${ }^{(81)}$ (Figure 5).

There was a report of a patient on mechanical ventilation who received a high oxygen flow in the stomach due to misconnection of the tube to the oxygen flow meter. The patient required surgery to repair the gastric perforation caused by the misconnection ${ }^{(83)}$.

\begin{tabular}{|c|c|c|c|}
\hline $\begin{array}{l}\text { Article } \\
\text { Number }\end{array}$ & Study Aim & Study Type & Main Results \\
\hline \multicolumn{4}{|c|}{ Esophageal or pharyngeal complications } \\
\hline 45 & $\begin{array}{l}\text { To report a case that illustrates } \\
\text { circumstances in which a narrow bore } \mathrm{NGT}^{*} \\
\text { was misplaced and where there could have } \\
\text { been serious consequences. }\end{array}$ & Case report & $\begin{array}{l}\text { An NGT }{ }^{*} \text { was inserted in a } 66 \text {-year-old patient. There was resistance } \\
\text { during the insertion and a new attempt was made. During the } \mathrm{pH} \\
\text { check, results were found outside the normal range. A radiograph was } \\
\text { performed and esophageal perforation was detected. The tube pierced } \\
\text { the mediastinum and punctured the pleura. The tube was removed and } \\
\text { the patient received antibiotic treatment. }\end{array}$ \\
\hline 46 & $\begin{array}{l}\text { To show that an acute and potentially } \\
\text { life-threatening situation may arise after } \\
\text { uneventful passage of an } \mathrm{NET}^{\dagger} \text {. }\end{array}$ & Case report & $\begin{array}{l}\text { After blind insertion of an } \mathrm{NET}^{\dagger} \text {, a } 56 \text {-yearl-old woman had large nasal } \\
\text { bleeding. The tube punctured the right internal jugular vein and traversed } \\
\text { the superior vena cava and the right atrium. She was quickly intubated } \\
\text { to ensure patent airway and two liters of blood were drained. Vasoactive } \\
\text { medication and intravenous blood infusion were also started. Patient was } \\
\text { transferred to another hospital. }\end{array}$ \\
\hline 47 & $\begin{array}{l}\text { To describe the clinical histories of two } \\
\text { representative cases among the four } \\
\text { patients and discuss the etiology of this } \\
\text { variant form of } \mathrm{NGT}^{*} \text { syndrome. }\end{array}$ & Case report & $\begin{array}{l}\text { After prolonged use of an } \mathrm{NGT}^{*} \text {, one patient developed laryngeal stridor } \\
\text { and severe vocal cord paralysis, as evidenced by laryngoscopy. The } \\
\text { patient progressed to severe respiratory disease and died. In the second } \\
\text { case, the patient presented laryngeal stridor, vocal cord paralysis and } \\
\text { glottic space crack after NGT' removal. After two months, the patient } \\
\text { presented exacerbated stridor and died due to respiratory failure. }\end{array}$ \\
\hline 48 & $\begin{array}{l}\text { To report a case of fatal hemorrhagic shock } \\
\text { immediately after NGT* insertion in a patient } \\
\text { undergoing debridement by video- assisted } \\
\text { thoracoscopic surgery for mediastinitis. }\end{array}$ & Case report & $\begin{array}{l}\text { An NGT* was inserted in a 70-year-old woman. During transport to the } \\
\text { ICU } \text { I }^{*} \text { the tube was accidentally pulled out and it was replaced by the } \\
\text { surgeon. After three attempts, there was a large amount of bleeding } \\
\text { through the tube and vital signs changed dramatically, with a decrease } \\
\text { in blood pressure and heart rate. Resuscitation maneuvers were } \\
\text { initiated and the opening of the ribcage was necessary for direct cardiac } \\
\text { compression. Four liters of blood were drained. Endoscopy revealed } \\
\text { esophageal perforation, which caused bleeding. The tube was removed } \\
\text { by endoscopy. Two days after the event, the pupils became fixed and the } \\
\text { patient died. }\end{array}$ \\
\hline 49 & $\begin{array}{l}\text { To report a case of a } 70 \text { year-old woman } \\
\text { who presented acute dyspnea, requiring } \\
\text { emergency tracheotomy following } \\
\text { prolonged nasogastric intubation. }\end{array}$ & Case report & $\begin{array}{l}\text { Patient required an NGT* for enteral nutrition. After five weeks, a new } \\
\text { tube was needed and after the insertion, the patient presented laryngeal } \\
\text { stridor, vocal cord paralysis and arytenoid edema. Urgent tracheostomy } \\
\text { was required. The tube was removed and parenteral nutrition was } \\
\text { started. The patient gradually recovered vocal cord mobility and was } \\
\text { diagnosed with Nasogastric Tube Syndrome. }\end{array}$ \\
\hline
\end{tabular}




\begin{tabular}{|c|c|c|c|}
\hline $\begin{array}{l}\text { Article } \\
\text { Number }\end{array}$ & Study Aim & Study Type & Main Results \\
\hline \multicolumn{4}{|c|}{ Esophageal or pharyngeal complications } \\
\hline 50 & $\begin{array}{l}\text { To present a case that highlights the } \\
\text { benefits of carrying out an X-ray to confirm } \\
\text { the position of a nasogastric tube. }\end{array}$ & Case report & $\begin{array}{l}\text { An NGT" for enteral nutrition was inserted in a 50-year-old man. After two } \\
\text { weeks, the tube was inserted several times due to accidental removal. } \\
\text { On one occasion, the patient reported traction of the tube while sleeping, } \\
\text { but the tube was not found. A new tube was inserted and its tip position } \\
\text { was confirmed by radiography. The x-ray revealed that the tube had been } \\
\text { inserted into the left main bronchus. It also revealed that the first tube } \\
\text { was in the hypopharynx region and the other end was in the stomach. } \\
\text { The "lost" tube was removed by esophagoscopy and there were no } \\
\text { complications to the patient. }\end{array}$ \\
\hline 51 & $\begin{array}{l}\text { To report an unexpected cause of } \\
\text { malfunctioning NGT due to non apparent } \\
\text { misplacement. }\end{array}$ & Case report & $\begin{array}{l}\text { An NGT* was blindly inserted in a 68-year-old man and positioning was } \\
\text { confirmed by abdominal radiography. Enteral nutrition was started and } \\
\text { the patient had vomiting. The attending physician reviewed the x-ray } \\
\text { showing positioning of the tube in the esophagus. }\end{array}$ \\
\hline 52 & $\begin{array}{l}\text { To present a case of nasopharyngeal } \\
\text { perforation caused by electromagnetically } \\
\text { visualized feeding tube system. }\end{array}$ & Case report & $\begin{array}{l}\mathrm{NET}^{\dagger} \text { was inserted with an electromagnetic device in a 50-year-old } \\
\text { woman and mechanically ventilated. Resistance occurred during } \\
\text { insertion; patient showed signs of respiratory distress and right side } \\
\text { dilation of the face. A tomography showed perforation of the right } \\
\text { nasopharynx. The tube traversed the anterior carotid artery, the internal } \\
\text { jugular vein, and the parotid gland. }\end{array}$ \\
\hline \multicolumn{4}{|c|}{ Tube obstruction } \\
\hline 53 & $\begin{array}{l}\text { To describe the management of patients } \\
\text { treated with enteral nutrition and to identify } \\
\text { complications and mortality. }\end{array}$ & $\begin{array}{l}\text { Prospective } \\
\text { observational } \\
\text { study }\end{array}$ & $\begin{array}{l}\text { From } 108 \text { patients included in the study, } 45 \text { used NET }{ }^{\dagger}, 62 \text { used } \\
\text { gastrostomy and one patient had jejunostomy. The following } \\
\text { complications were observed: aspiration (15\%); accidental removal }(62 \%) \\
\text { and tube obstruction ( } 11 \%) \text {. The mortality rate was } 23 \% \text { in one year and } \\
\text { the average survival was } 674 \text { days. }\end{array}$ \\
\hline 54 & $\begin{array}{l}\text { To identify adverse events related to enteral } \\
\text { nutrition in hospitalized patients }\end{array}$ & $\begin{array}{l}\text { Longitudinal } \\
\text { exploratory } \\
\text { study }\end{array}$ & $\begin{array}{l}46 \text { patients were observed and the most common adverse events were: } \\
\text { accidental removal }(43 \%) \text { and tube obstruction }(21 \%) \text {. Nausea and } \\
\text { vomiting were also recorded. }\end{array}$ \\
\hline 55 & $\begin{array}{l}\text { To report a case of a patient who } \\
\text { developed an esophageal bezoar due to } \\
\text { malpositioning of an NGT. }\end{array}$ & Case report & $\begin{array}{l}\text { An NGT* was inserted into a 20-year-old patient. Positioning was } \\
\text { confirmed by auscultation. Patient had aspiration pneumonia and the } \\
\text { nurse found tube obstruction. A new tube was inserted and, again, } \\
\text { obstruction was detected due to bezoar. }\end{array}$ \\
\hline \multicolumn{4}{|c|}{ Intestinal perforation } \\
\hline 56 & $\begin{array}{l}\text { To describe a case where insertion of an } \\
\text { NGT" caused intestinal perforation in a } \\
\text { patient who had previously undergone } \\
\text { Roux-en-Y gastric bypass. }\end{array}$ & Case report & $\begin{array}{l}\text { An orogastric tube was inserted in a 59-year-old patient for gastric } \\
\text { decompression. Positioning was confirmed by radiography. In the } \\
\text { ICU }{ }^{\ddagger}, \text { the tube was replaced by an NET } \\
\text { was inserted and } 11 \text { days later, a distended abdomen } 28^{\text {th }} \text { day, a new } \mathrm{NET}^{\dagger} \\
\text { of airborne noises were observed. The patient progressed to clinical } \\
\text { worsening and on the } 39^{\text {th }} \text { day, the patient died. At necropsy, intestinal } \\
\text { perforation was found in the bypass region caused by the insertion of the } \\
\text { last tube. }\end{array}$ \\
\hline \multicolumn{4}{|c|}{ Intracranial perforation } \\
\hline 57 & $\begin{array}{l}\text { To describe a case in which a patient } \\
\text { who had suffered severe facial fractures } \\
\text { erroneously had an NGT" placed in the } \\
\text { intracranial cavity. }\end{array}$ & Case report & $\begin{array}{l}\text { A 34-year-old woman falls from the height of a building and suffers head } \\
\text { and neck trauma. An NGT' was blindly inserted for gastric decompression } \\
\text { and minutes later the patient had dilated pupils, ataxic breathing, and } \\
\text { flaccid body. Radiography revealed that the tube surpassed the cribriform } \\
\text { plate and that the distal tip was inserted into the intracranial cavity. The } \\
\text { patient's condition deteriorated and she died after one hour. }\end{array}$ \\
\hline 58 & $\begin{array}{l}\text { To report a case of inadvertent intracranial } \\
\text { complication directly related to the } \\
\text { placement of an NGT' in a patient who had } \\
\text { no history of head trauma. }\end{array}$ & Case report & $\begin{array}{l}\text { An NGT" was inserted into a conscious and oriented } 45-\text {-year-old woman } \\
\text { with no previous history of head injury. During the insertion, there was } \\
\text { return of live blood in the tube. The procedure was continued and } \\
\text { the auscultation test was negative. The tube was removed and the } \\
\text { patient became irresponsive. Computed tomography revealed subdural } \\
\text { pneumocephalus of the skull and sinusitis in the frontal sinuses, with air } \\
\text { collections. }\end{array}$ \\
\hline 59 & $\begin{array}{l}\text { To report a case of inadvertent intracranial } \\
\text { placement of an NGT' in a non-trauma } \\
\text { patient. }\end{array}$ & Case report & $\begin{array}{l}\text { An NGT* was inserted into a 59-year-old woman. Three attempts were } \\
\text { made and blood returned in all. In the third attempt, an x-ray was } \\
\text { performed, which found the presence of the tube in the brain. The tube } \\
\text { was removed, but the patient died of sepsis. }\end{array}$ \\
\hline 60 & $\begin{array}{l}\text { To describe a case of severe craniofacial } \\
\text { fracture in which an NGT' was positioned } \\
\text { intracranially. }\end{array}$ & Case report & $\begin{array}{l}\text { An NGT* was inserted into a } 38 \text {-year-old man with skull and facial bone } \\
\text { base fractures. There were no clinical signs showing NGT* misplacement. } \\
\text { After computed tomography, it was found that the tube was located in the } \\
\text { cranial fossa. }\end{array}$ \\
\hline 61 & $\begin{array}{l}\text { To describe a case of severe craniofacial } \\
\text { fracture in which the NGT' was positioned } \\
\text { intracranially. }\end{array}$ & Case report & $\begin{array}{l}\text { NGT" was inserted in a 53-year-old man with polytraumas. Skull base } \\
\text { fracture was found and computed tomography revealed traumatic } \\
\text { subarachnoid hemorrhage. The exam also revealed that the NGT" crossed } \\
\text { the cribriform plate and reached the posterior cranial fossa. The tube was } \\
\text { removed and the patient was transferred to the ICUł. A drain was installed } \\
\text { as well as a transducer for intracranial pressure monitoring. The next } \\
\text { day, the patient presented hemiplegia on the right. The patient was only } \\
\text { discharged after } 80 \text { days of hospitalization with neurological complications. }\end{array}$ \\
\hline
\end{tabular}




\begin{tabular}{|c|c|c|c|}
\hline $\begin{array}{c}\text { Article } \\
\text { Number }\end{array}$ & Study Aim & Study Type & Main Results \\
\hline \multicolumn{4}{|c|}{ Unplanned Tube Removal } \\
\hline 62 & $\begin{array}{l}\text { To characterize the rates of accidental } \\
\text { removal of endotracheal tubes, vascular } \\
\text { catheters, and nasogastric tubes in the } \\
\text { critically ill patient. }\end{array}$ & $\begin{array}{l}\text { Prospective } \\
\text { observational } \\
\text { study }\end{array}$ & $\begin{array}{l}\text { In total, } 532 \mathrm{ICU}^{\ddagger} \text { patients were included and } 913 \mathrm{NGT}^{*} \text { were inserted. } \\
\text { Regarding accidental withdrawal, } 312 \text { cases were reported, and the most } \\
\text { common reason was withdrawal by the patient her/himself. }\end{array}$ \\
\hline 63 & $\begin{array}{l}\text { To characterize adverse events in ICU } \\
\text { Semi-Intensive Care Units and Inpatient } \\
\text { Units, regarding nature, type, day of the } \\
\text { week and nursing professionals/patient } \\
\text { ratio at the moment of occurrence; as well } \\
\text { as to identify nursing interventions after the } \\
\text { event. }\end{array}$ & $\begin{array}{l}\text { Retrospective } \\
\text { observational } \\
\text { study }\end{array}$ & $\begin{array}{l}\text { The main adverse events were related to } \mathrm{NGT}^{*} / \mathrm{NET}^{+}: 69.6 \% \text { were } \\
\text { caused by accidental removal and } 54.10 \% \text { by tube obstruction. }\end{array}$ \\
\hline
\end{tabular}

${ }^{*}$ NGT $=$ Nasogastric tube $;{ }^{+}$NET $=$Nasoenteric tube $;{ }^{\circledR} \mathrm{ICU}=$ Intensive Care Unit

Figure 4 - Key features of the NGT/NET-related adverse events described in included articles. Ribeirão Preto, SP, Brazil, 2018

\begin{tabular}{|c|c|c|c|}
\hline $\begin{array}{l}\text { Article } \\
\text { Number }\end{array}$ & Study Aim & Study Type & Main Results \\
\hline \multicolumn{4}{|c|}{ Pressure Injury Related to Fixation } \\
\hline 64 & $\begin{array}{l}\text { To find out the incidence of patients with } \\
\text { nasal pressure ulcer, study the risks factors } \\
\text { for its development and find the predictable } \\
\text { variables. }\end{array}$ & $\begin{array}{l}\text { Prospective } \\
\text { observational } \\
\text { study }\end{array}$ & $\begin{array}{l}\text { Pressure injury related to } \mathrm{NGT}^{*} / \mathrm{NET}^{+} \text {fixation was found in } 25.2 \% \text { of } \\
\text { all patients included in the study }(n=115) .\end{array}$ \\
\hline \multicolumn{4}{|c|}{ Misconnections } \\
\hline 65 & $\begin{array}{l}\text { To determine if critically ill adult patients } \\
\text { could be safely intubated at their bedside, } \\
\text { and which complications might occur } \\
\text { when the procedure is not controlled } \\
\text { fluoroscopicaly. }\end{array}$ & $\begin{array}{l}\text { Prospective } \\
\text { observational } \\
\text { study }\end{array}$ & $\begin{array}{l}314 \text { patients were enrolled in the study who required an } \mathrm{NET}^{\dagger} \text {. From } \\
\text { those: } \\
\text { - the tube was positioned in the airway in } 7 \text { patients }(2.22 \%) \text {. } \\
\text { - The tube was positioned in the esophagus in } 8(2.54 \%) \text { patients and } \\
\text { it resulted in bronchoaspiration. } \\
\text { - the tube entered the stomach, but made a turn and returned to the } \\
\text { esophagus in } 2 \text { patients }(0.64 \%) \text {. } \\
\text { - An AE occurred due to mercury leakage in the stomach of the } \\
\text { distal end of the tube. This event occurred because the tube was } \\
\text { wrapped around the stomach, which resulted in increased pressure } \\
\text { and disconnection of mercury weight from the distal tip. The tube } \\
\text { was removed and the mercury was gradually eliminated by the } \\
\text { gastrointestinal system. }\end{array}$ \\
\hline 66 & $\begin{array}{l}\text { To report a case of a 77-year-old woman } \\
\text { who had an inadvertent fatal administration } \\
\text { of enteral feed via a venous catheter. }\end{array}$ & Case report & $\begin{array}{l}\text { Patient received inadvertent infusion of enteral nutrition into } \\
\text { the bloodstream via central venous catheter. Patient presented } \\
\text { tachycardia, dyspnea and death after six hours of the event. }\end{array}$ \\
\hline 67 & $\begin{array}{l}\text { To report a case of a } 74 \text {-year-old woman } \\
\text { who had enteral formulas given by the } \\
\text { wrong route. }\end{array}$ & Case report & $\begin{array}{l}\text { Medication was administered into the patient's vein, who showed a } \\
\text { rapid decline in consciousness and in respiratory function. The patient } \\
\text { was intubated and required thoracic drainage. The patient evolved to } \\
\text { sepsis and required tracheostomy. She was clinically stable and after } \\
\text { a few days and she was extubated. She was discharged after eight } \\
\text { weeks of the event. }\end{array}$ \\
\hline 68 & $\begin{array}{l}\text { To report a case of a } 48 \text {-year-old man } \\
\text { who had gastric acid burns because of a } \\
\text { disconnected nasogastric tube. }\end{array}$ & Case report & $\begin{array}{l}\text { Stroke patient restricted to bed presented } 8 \% \text { of burned body due to } \\
\text { tube disconnection. The patient recovered after skin grafting. }\end{array}$ \\
\hline 69 & $\begin{array}{l}\text { To report a case of enteral feeding tube } \\
\text { misconnection reported to the FDA }{ }^{\ddagger} \text {. }\end{array}$ & Case report & $\begin{array}{l}\text { High-flow oxygen was accidentally connected to the } \mathrm{NGT}^{\star} \text {. The } \\
\text { patient underwent emergency surgery to repair the gastric perforation } \\
\text { and colonic serosal tear resulting from the improper connection. }\end{array}$ \\
\hline
\end{tabular}

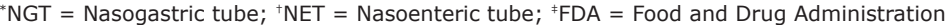

Figure 5 - Key features of the Category 2: Other Incidents described in included articles. Ribeirão Preto, São Paulo, Brazil, 2018 


\section{Discussion}

Most NGT/NET-related AEs identified in this integrative review involved respiratory complications. However, other events were also identified, such as intestinal and intracranial perforation, tube obstruction, esophageal harm, unplanned tube removal, fixationrelated pressure injury, and misconnection. In addition, 16 articles reported patient death as a consequence of the event.

Although considered a relatively simple and innocuous procedure, bedside insertion of an NGT/NET is associated with severe AEs. In addition, more than $88 \%$ of nurses are using non-evidence based methods for verification of NGT placement leading to serious patient harm ${ }^{(84)}$ and raising an important safety concern.

AEs related to misplaced NGT/NET can range from pneumothorax, requiring chest tube placement, to profound chemical pneumonitis and respiratory distress syndrome(84). In this integrative review, the largest number of articles was grouped into the subcategory Respiratory complications, revealing that this was the main $A E$ related to this medical device. Previous studies showed that patients had an NGT/NET inserted into the airway, resulting in pneumothorax. This event can be catastrophic, especially in critically ill patients, and according to the articles, pneumothorax occurred mainly because the tube was placed blindly at the patient bedside.

Respiratory AEs may also occur due to failure to recognize when an NGT/NET has changed position ${ }^{(84)}$ and when the methods used to verify its placement are inconclusive ${ }^{(85)}$. Healthcare professionals should be aware of these potential risks, especially in critically ill patients $^{(86)}$.

Despite the risks, no universal standard of practice exists for bedside verification because each method has limitations ${ }^{(84)}$. There is a consensus among the international guidelines though about practices that should never be used to confirm blindly inserted feeding tubes, which include: auscultation ${ }^{(1,84)}$, visual inspection of fluid from the tube ${ }^{(1,84)}$, and observation of water bubbles ${ }^{(84)}$

An x-ray, when properly performed and interpreted, is the most accurate method for distinguishing between gastric and pulmonary placement of a newly inserted NGT/NET and it is generally supported for highrisk patients (such as patients who are critically ill or have an altered level of consciousness or diminished or absent gag reflex)(1). The existing British National Health Services (NHS) Improvement safety guideline recommends the $\mathrm{pH}$ method as first-line testing for initial NGT placement though. According to this guideline,
$\mathrm{pH} \leq 5.5$ is considerate safe and this range excludes placement in the respiratory tract( ${ }^{(87)}$. For blind inserted $\mathrm{NET}$, an $\mathrm{x}$-ray remains the safest method to confirm the tip position.

Nurses should also be aware that once correct NGT placement is confirmed, the exit site from the patient's nose or mouth should be immediately marked and documented. In addition, after feedings are started, tube location should be checked at four-hour intervals(88).

Several technologies are available to assist nurses during NGT/NET insertion, but specialists argue that lack of availability of special testing equipment, such as carbon dioxide detectors and enteral access devices, in routine clinical settings is a limiting factor for their use, and the evidence base for their accuracy has not been established ${ }^{(1)}$. Thus, based on research and best practices from the NHS Improvement and the New Opportunities for Verification of Enteral Tube Location (NOVEL) project from the American Society for Parenteral and Enteral Nutrition (ASPEN), evidence-based best practices to verify NGT placement include: nose-ear-mid umbilicus measurement (NEMU) every time an NGT is inserted (from the tip of the patient's nose to the earlobe and from the earlobe to the point midway between the xiphoid process and umbilicus), $\mathrm{pH}$ testing, $\mathrm{x}$-rays, and critical-thinking skills ${ }^{(84)}$.

Although patient outcomes are more severe when enteral nutrition is given to the lungs, esophageal/ pharyngeal AEs can also cause significant harm, such as perforation of the pharynx, carotid artery and internal jugular vein. Among the AEs in the pharyngeal region, the Nasogastric Tube Syndrome was mentioned in two case reports included in this review. This syndrome consists of bilateral vocal cord paralysis accompanied by supraglottic edema. Despite being a rare syndrome, it can be considered fatal( ${ }^{(89)}$. The triggering mechanism of the syndrome is the passage of the tube through the muscles present in the vocal cord region and the compression of bones against the spine, causing an inflammatory process. In addition, the primary symptoms are nonspecific, such as irritation and pain. However, in the Nasogastric Tube Syndrome, laryngeal stridor and vocal cord paralysis also occur. With proper treatment, the patient can slowly regain normal vocal cord mobilization ${ }^{(89)}$.

The pharyngeal complications identified in this review occurred because NGT/NET were blindly inserted at the bedside, making it impossible for the healthcare professional to visualize the route of the tube into the gastrointestinal tract (GIT). Due to resistance during insertion, caution is necessary in order to avoid perforation of internal organs. In addition, nurses should 
monitor patients with NGT/NET to manage risks and improve patient outcomes.

Another AE found in this study was intestinal perforation, which can be fatal due to subsequent infection. In one study, intestinal perforation occurred because the NET deviated at the bypass site. This does not mean that patients undergoing this type of surgical intervention are more prone to AEs. It should be emphasized, however, that the feeding tubes were designed for insertion in normal GIT. Therefore, in individuals with a different tract, both due to congenital defects and previous surgeries that caused anastomosis, the tubes should be inserted with the help of technologies that permit their real-time view ${ }^{(90)}$. The electromagnetic device is one such technology. A Brazilian study found that post-pyloric insertion of the tube guided by this device was faster and more efficient when compared to pH-testing ${ }^{(91)}$.

Another technology available to assist the practitioner during tube insertion is fluoroscopy. This method enables the tube path to be delineated through water-soluble contrast. Thus, this method allows the NGT/NET to be monitored in real time during insertion. The disadvantage is that it cannot be performed at the bedside, however, researchers reported that the success rate was $90 \%$ when using fluoroscopy guidance ${ }^{(92)}$.

The endoscopy method may also be appropriate for post-pyloric tube positioning. This method permits real-time visualization during tube insertion. Although considered a high-cost procedure that requires intravenous sedation, researchers showed a high success rate $(98 \%)^{(93-94)}$.

Feeding tube insertion into the intracranial region is one of the most severe feeding tubes-related AEs. In the case reports included in this review, the tube penetrated the intracranial region due to the rupture of the cribriform plaque. Treatment in these cases consists of removing the tube and initiating antibiotics therapy when necessary. The mortality rate can be up to $60 \%$, so extra precautions should be considered when inserting feeding tubes in patients with cranial fractures(75). In these patients, the oropharyngeal route should be adopted, preferably with the help of an endoscope or laryngoscope, because they permit a direct view of the tube path. It is also recommended to use more calibrated tubes, preventing them from bending or being inadvertently diverted to an unwanted region ${ }^{(95)}$.

Regarding tube obstruction, in most cases, it is an event that occurs due to errors in tube handling, so nurses need to be attentive and follow the manufacturer's norms ${ }^{(96)}$. In one study, the obstruction was related to the formation of bezoar. Bezoars are non-digestive conglomerates that accumulate in the tube, which may be, for example, medicines, enteral feeding and food residues. In the case presented in this integrative review, bezoar was formed by the enteral formulas that accumulated along the tube. Obstruction prevention requires safe practices in the handling of feeding tubes, which include checking the compatibility of the grinding and medication administration, crushing oral formulas until a fine powder, ensure feed is stopped prior to medication administration, administering medicines separately and washing the tube between administrations ${ }^{(97-98)}$.

In relation to unplanned feeding tube withdrawal, it can occur for several reasons, such as the health team itself, the patient and/or caregiver. Some interventions implemented in an ICU of a hospital in Rio de Janeiro, Brazil, decreased the frequency of unplanned removal, such as the evaluation of the presence of delirium or dementia, guidelines to the caregivers and mechanical restraint, when prescribed by the medical team, until agitation decreases ${ }^{(99)}$.

As a nursing intervention to reduce the risk of unplanned removal, researchers developed a technique that should be performed prior to the insertion of NGT/ NETs. The technique consists of using two NETs, one inserted in each nostril. The two tubes are inserted into the oropharynx so that the distal tips progress to the oral cavity. The practitioner then ties the two distal tips with a knot, pulls one of the proximal tips until the knot protrudes through the nostril. About 16 $\mathrm{cm}$ of tube should be exposed, starting from the nostril. Thus, the NGT/NET is inserted through the GIT and tied underneath the prepared mechanism; one should leave about two inches for patient comfort and then fix the tube with hypoallergenic adhesive tape ${ }^{(100)}$. An English study found that, when this method is used, it saves approximately $£ 3,288$ per year. Therefore, this technology may be economically feasible because unplanned tube removal requires new insertion and new material consumption ${ }^{(101)}$.

The insertion of NGT/NET can be considered the most physiological means to permit enteral feeding in patients who are unable to receive oral feeding. These devices can cause discomfort and complications for the patient though, due to the material they are made of and to the nasal access. Nasal pressure injury is not a severe complication, however, this $\mathrm{AE}$ is avoidable through good nursing practices, such as the movement of the tube every 24 hours. The feeding tube is an external agent, therefore, its long dwelling time, without daily movement, can cause injury and discomfort ${ }^{(78)}$.

Continuing nursing education may help to reduce this type of AE. Nurses should be trained to move the tube in order to reduce pressure injury. In addition, 
preference should be given to the use of flexible and lubricated tubes ${ }^{(102)}$.

Misconnections can lead to serious AEs for patients and be related to medical devices (such as the NGT/NET itself, venous catheters and oxygen therapy devices). It was noticed that several devices had a Luer connection and that the enteral cable set could be connected to the venous access for example. To reduce these $A E$, the International Organization for Standardization (ISO) has implemented standards for connectors that connect only to devices with the same final objective. Thus, the connector of the enteral cable set is expected to be incompatible with the venous catheter connector. The devices also present different colors to attract the attention of the professional and avoid a possible connection error ${ }^{(103-104)}$.

Organizational managers and leaders should rethink the procurement processes of these devices to promote safety for tube-fed patients and reduce the costs of AE. They should also work with manufacturers to encourage the creation of new alternatives to solve the problems related to medical devices ${ }^{(105)}$.

While efforts were made to uphold rigor for an integrative review and a comprehensive literature search was done, we acknowledge that this review has some limitations. First, only those articles available for free were included. This may have resulted in the omission of several valuable studies. Second, this review did not take into consideration the characteristics of the patients with an NGT/NET such as age, inpatient unit and time of use. These factors may contribute to AEs. Last, articles with similar research that did not use our broad search criteria may have been automatically excluded during the initial search.

\section{Conclusion}

Sixty-nine primary articles were included in this review, and AEs were mostly respiratory; in 16 articles, death was reported. Although respiratory AEs were the most common, other equally severe AEs were identified, such as $8 \%$ burned body surface due to extravasation of gastric juice, enteral feeding into the bloodstream, and organ perforations.

The results may also contribute to healthcare professionals, especially nurses, to develop evidencebased guidelines for inserting feeding tubes at patients' bedside and for verifying feeding tubes placement in adult patients. Incorporating technological advances in patient care is not easy. These advances are fundamental tools though for the reduction of $A E$ and for the quality and safety of the patient.
This is the first integrative review on adverse events caused by NGT/NET around the world to date. Future experimental research is needed to test the feasibility and efficiency of technologies already available to improve clinical practice and patient safety. In addition, future studies should establish the patients' factors that may lead to NGT/NET-related AEs in order to reduce risks and improve patient outcomes.

\section{References}

1. Metheny NA, Krieger MM, Healey F, Meert KL. A review of guidelines to distinguish between gastric and pulmonary placement of nasogastric tubes. Heart Lung. 2019;48(3):226-35. doi: http://dx.doi.org/10.1016/j. hrtlng.2019.01.003

2. NHS Improvement. Never events list 2018. [Internet]. London: NHS Improvement; 2018 [cited May 24, 2019]. Available from: https://improvement.nhs.uk/ documents/2266/Never_Events_list_2018_FINAL_v5.pdf 3. World Health Organization. Conceptual framework for the international classification for patient safety. [Internet]. Geneva: WHO; 2009 [cited May 24, 2019]. Available from: https://www.who.int/patientsafety/ taxonomy/icps_full_report.pdf

4. Fan L, Liu Q, Gui L. Efficacy of non-swallow nasogastric tube intubation: a randomized controlled trial. J Clin Nurs. 2017;25(21-22):3326-32. doi: https://doi. org/10.1111/jocn.13398

5. Brooks M. Pneumothorax events linked to placement of enteral feeding tube. [Internet]. New York: Medscape; 2018 [cited May 24, 2019]. Available from: https:// www.medscape.com/viewarticle/891200

6. Lamont T, Beaumont C, Fayaz A, Healey F, Huehns $T$, Law $R$, et al. Checking placement of nasogastric feeding tubes in adults (interpretation of $x$ ray images): summary of a safety report from the National Patient Safety Agency. BMJ. 2011;342:d2586. doi: https://doi. org/10.1136/bmj.d2586

7. NHS Improvement. Provisional publication of Never Events reported as occurring between 1 April and 30 November 2017. [Internet]. London: NHS Improvement; 2017 [cited May 24, 2019]. Available from: https://improvement.nhs.uk/documents/2479/ Never_Events_1_April_2017_-_31_January_2018_ FINAL_v2.pdf

8. Volpe CRG, Aguiar LB, Pinho DLM, Stival MM, Funghetto SS, Lima LR. Erros de medicação divulgados na mídia: estratégias de gestão do risco. Rev Adm Hosp Inov Saúde. 2016;13(2):97-110. doi: https://doi. org/10.21450/rahis.v13i2.3499

9. Blumenstein I, Shastri YM, Stein J. Gastroenteric tube feeding: techniques, problems and solutions. World J 
Gastroenterol. 2014;20(26):8505-24. doi: https://doi. org/10.3748/wjg.v20.i26.8505

10. Aguilar-Nascimento JE, Kudsk KA. Use of small-bore feeding tubes: successes and failures. Curr Opin Clin Nutr Metab Care. 2007;10(3):291-6. doi: https://doi. org/10.1097/MCO.0b013e3280d64a1d

11. Gimenes FRE, Pereira MCA, Prado PRD, Carvalho R, Koepp J, Freitas LM, et al. Nasogastric/Nasoenteric tube-related incidents in hospitalised patients: a study protocol of a multicentre prospective cohort study. BMJ Open. 2019;9(7):e027967. doi: http://dx.doi. org/10.1136/bmjopen-2018-027967

12. Ferreira AM. Sondas nasogástricas e nasoentéricas: como diminuir o desconforto na instalação? Rev Esc Enferm USP. [Internet]. 2005 [Acesso 24 mai 2019];39(3):358-9. Disponível em: http://www.scielo. br/pdf/reeusp/v39n3/15.pdf

13. Ganong LH. Integrative reviews of nursing research. Res Nurs Health. 1987;10(1):1-11. doi: https://doi. org/10.1002/nur.4770100103

14. Melnyk BM, Fineout-Overholt E. Evidence-basedpractice in nursing and healthcare: a guide to best practice. $3^{\text {th }}$ ed. Baltimore: LWW; 2011.

15. Ursi ES, Galvão CM. Prevenção de lesões de pele no perioperatório: revisão integrativa da literatura. Rev. Latino-Am. Enfermagem. [Internet]. 2006 [Acesso 24 mai 2019];14(1):124-31. Disponível em: http://www. scielo.br/pdf/rlae/v14n1/v14n1a17.pdf

16. Liberati A, Altman DG, Tetzlaff J, Mulrow C, Gotzsche PC, Ioannidis JP, et al. The PRISMA statement for reporting systematic reviews and meta-analyses of studies that evaluate healthcare interventions: explanation and elaboration. PLoS Med. 2009;6(7):e1000100. doi: https://doi.org/10.1371/journal.pmed.1000100

17. Kearns PJ, Chin D, Mueller L, Wallace K, Jensen WA, Kirsch CM. The incidence of ventilator-associated pneumonia and success in nutrient delivery with gastric versus small intestinal feeding: a randomized clinical trial. Crit Care Med. 2000;28(6):1742-6. doi: https:// doi.org/10.1097/00003246-200006000-00007

18. Attanasio A, Bedin M, Stocco S, Negrin V, Biancon A, Cecchetto $G$, et al. Clinical outcomes and complications of enteral nutrition among older adults. Minerva Med. [Internet]. 2009 [cited May 24, 2019];100(2):159-66. Available from: https://www. minervamedica.it/en/journals/minerva-medica/article. php?cod=R10Y2009N02A0159

19. Neumann DA, DeLegge MH. Gastric versus small-bowel tube feeding in the intensive care unit: A prospective comparison of efficacy. Critical Care Medicine. 2002;30(7):1436-8. doi: https://doi. org/10.1097/00003246-200207000-00006
20. Rassias AJ, Ball PA, Corwin HL. A prospective study of tracheopulmonary complications associated with the placement of narrow-bore enteral feeding tubes. Crit Care. 1998;2(1):25-8. doi: https://doi.org/10.1186/ cc120

21. Lin LC, Hsieh PC, Wu SC. Prevalence and associated factors of pneumonia in patients with vegetative state in Taiwan. J Clin Nurs. 2008;17(7):861-8. doi: https://doi. org/10.1111/j.1365-2702.2006.01883.x

22. McWey RE, Curry NS, Schabel SI, Reines HD. Complications of nasoenteric feeding tubes. Am J Surg. 1988;155(2):253-7. doi: https://doi.org/10.1016/ s0002-9610(88)80708-6

23. Bankier AA, Wiesmayr MN, Henk C, Turetschek K, Winkelbauer $F$, Mallek $R$, et al. Radiographic detection of intrabronchial malpositions of nasogastric tubes and subsequent complications in intensive care unit patients. Intensive Care Med. 1997;23(4):406-10. doi: https:// doi.org/10.1007/s001340050348

24. Marderstein EL, Simmons RL, Ochoa JB. Patient safety: effect of institutional protocols on adverse events related to feeding tube placement in the critically ill. J Am Coll Surg. 2004;199(1):39-47. doi: https://doi. org/10.1016/j.jamcollsurg.2004.03.011

25. Metheny NA, Stewart BJ, McClave SA. Relationship between feeding tube site and respiratory outcomes. JPEN J Parenter Enteral Nutr. 2011;35(3):346-55. doi: https://doi.org/10.1177/0148607110377096

26. Marco J, Barba R, Lazaro M, Matia P, Plaza S, Canora $\mathrm{J}$, et al. Bronchopulmonary complications associated to enteral nutrition devices in patients admitted to internal medicine departments. Rev Clin Esp (Barc). 2013;213(5):223-8. doi: https://doi.org/10.1016/j. rce.2013.01.009

27. Sweatman AJ, Tomasello PA, Loughhead MG, Orr M, Datta T. Misplacement of nasogastric tubes and oesophageal monitoring devices. $\mathrm{Br} \mathrm{J}$ Anaesth. 1978;50(4):389-92. doi: https://doi.org/10.1093/ bja/50.4.389

28. Vaughan ED. Hazards associated with narrow bore naso-gastric tube feeding. $\mathrm{Br} J$ Oral Surg. 1981;19(2):151-4. doi: https://doi.org/10.1016/0007$117 \times(81) 90043-3$

29. Balogh GJ, Adler SJ, Van der Woude J, Glazer HS, Roper C, Weyman PJ. Pneumothorax as a complication of feeding tube placement. AJR Am J Roentgenol. 1983;141(6):1275-7. doi: https://www.ajronline.org/ doi/pdf/10.2214/ajr.141.6.1275

30. McDanal JT, Wheeler DM, Ebert J. A complication of nasogastric intubation: pulmonary hemorrhage. Anesthesiology. 1983;59(4):356-8. doi: https://doi. org/10.1097/00000542-198310000-00018 
31. Schorlemmer GR, Battaglini JW. An unusual complication of naso-enteral feeding with small-diameter feeding tubes. Ann Surg. 1984;199(1):104-6. doi: https://doi.org/10.1097/00000658-198401000-00018

32. Harris CR, Filandrinos D. Accidental administration of activated charcoal into the lung: aspiration by proxy. Ann Emerg Med. 1993;22(9):1470-3. doi: https://doi. org/10.1016/s0196-0644(05)81998-5

33. Thomas B, Cummin D, Falcone RE. Accidental pneumothorax from a nasogastric tube. N Engl J Med. 1996;335(17):1325. doi: https://doi.org/10.1056/ NEJM199610243351717

34. Kolbitsch C, Pomaroli A, Lorenz I, Gassner M, Luger TJ. Pneumothorax following nasogastric feeding tube insertion in a tracheostomized patient after bilateral lung transplantation. Intensive Care Med. 1997;23(4):440-2. doi: https://doi.org/10.1007/s001340050354

35. Metheny NA, Aud MA, Ignatavicius DD. Detection of improperly positioned feeding tubes. J Healthc Risk Manag. 1998;18(3):37-48. doi: https://doi. org/10.1002/jhrm.5600180307

36. Winterholler M, Erbguth FJ. Accidental pneumothorax from a nasogastric tube in a patient with severe hemineglect: a case report. Arch Phys Med Rehabil. 2002;83(8):1173-4. doi: https://doi.org/10.1053/ apmr.2002.33643

37. Kannan S, Morrow B, Furness G. Tension pneumothorax and pneumomediastinum after nasogastric tube insertion. Anaesthesia. 1999;54(10):1012-3. doi: https://doi.org/10.1046/j.1365-2044.1999.1133k.x

38. Howell G, Shriver RL. Hydropneumothorax caused by inadvertent placementof a Dobhoff tube. Hosp Physician. [Internet]. 2005 [cited May 24, 2019];41(11):39-41. Available from: http://www.hospitalphysician.com/ memberfile.php?PubCode=hp_nov05_tube.pdf

39. O'Neil R, Krishnananthan R. Intrapleural nasogastric tube insertion. Australas Radiol. 2004;48(2):139-41. doi: https://doi.org/10.1111/j.1440-1673.2004.01274.x 40. Pillai JB, Vegas A, Brister S. Thoracic complications of nasogastric tube: review of safe practice. Interact Cardiovasc Thorac Surg. 2005;4(5):429-33. doi: https://doi.org/10.1510/icvts.2005.109488

41. Kawati R, Rubertsson S. Malpositioning of fine bore feeding tube: a serious complication. Acta Anaesthesiol Scand. 2005;49(1):58-61. doi: https://doi.org/10.1111/ j.1399-6576.2005.00508.x

42. De Giacomo T, Venuta F, Diso D, Coloni GF. Successful treatment with one-way endobronchial valve of large airleakage complicating narrow-bore enteral feeding tube malposition. Eur J Cardiothorac Surg. 2006;30(5):8112. doi: https://doi.org/10.1016/j.ejcts.2006.08.005 43. Haas LE, Tjan DH, van Zanten AR. "Nutrothorax" due to misplacement of a nasogastric feeding tube. Neth J
Med. [Internet]. 2006 [cited May 24, 2019];64(10):3856. Available from: http://www.njmonline.nl/getpdf. php?id $=472$

44. Freeberg SY, Carrigan TP, Culver DA, Guzman JA. Case series: tension pneumothorax complicating narrow-bore enteral feeding tube placement. J Intensive Care Med. 2010;25(5):281-5. doi: https://doi. org/10.1177/0885066610371185

45. Lemyze $M$, Brown D. Aspiration by proxy. Intern Med J. 2010;40(7):535. doi: https://doi.org/10.1111/ j.1445-5994.2010.02271.x

46. Lo JO, Wu V, Reh D, Nadig S, Wax MK. Diagnosis and management of a misplaced nasogastric tube into the pulmonary pleura. Arch Otolaryngol Head Neck Surg. 2008;134(5):547-50. doi: https://doi.org/10.1001/ archotol.134.5.547

47. Wang PC, Tseng GY, Yang HB, Chou KC, Chen $\mathrm{CH}$. Inadvertent tracheobronchial placement of feeding tube in a mechanically ventilated patient. J Chin Med Assoc. 2008;71(7):365-7. doi: https://doi.org/10.1016/ S1726-4901(08)70141-2

48. Ishigami A, Kubo S, Tokunaga I, Gotohda T, Nishimura A. An autopsy case of severe pleuritis induced by misinsertion of a nasogastric nourishment tube: diagnostic significance of multinucleated giant cells. Leg Med (Tokyo). 2009;11(4):191-4. doi: https://doi. org/10.1016/j.legalmed.2009.02.065

49. Takwoingi YM. Inadvertent insertion of a nasogastric tube into both main bronchi of an awake patient: a case report. Cases J. 2009;2:6914. doi: https://doi. org/10.1186/1757-1626-2-6914

50. Chhavi S, Dev SK, Pramendra A. Accidental tracheal intubation of feeding tube. Int J Nurs Educ. [Internet]. 2010 [cited May 24, 2019];2(1):5-6. Available from: http://www.indianjournals.com/ijor.aspx?target=ijor:ijo ne\&volume $=2 \&$ issue $=1 \&$ article $=003$

51. Luo RB, Zhang M, Gan JX. Tracheobronchial malposition of fine bore feeding tube in patients with mechanical ventilation. Crit Care. 2011;15(6):454. doi: https://doi.org/10.1186/cc10520

52. Shaikh N, Patil P, Mudali IN, Gafoor MT, Umminnisa F. Blind nasogastric tube insertion: be careful. Qatar Med. J. 2010;19(2):69-71. doi: 10.5339/qmj.2010.2.23

53. Sellers CK. False-positive $\mathrm{pH}$ aspirates after nasogastric tube insertion in head and neck tumour. BMJ Case Rep. 2012;2012:bcr2012006591. doi: https://doi. org/10.1136/bcr-2012-006591

54. Amirlak B, Amirlak I, Awad Z, Zahmatkesh M, Pipinos I, Forse A. Pneumothorax following feeding tube placement: precaution and treatment. Acta Med Iran. [Internet]. 2012 [cited May 25, 2019];50(5):355-8. Available from: http://acta.tums.ac.ir/index.php/acta/ article/view/3912 
55. Raut MS, Joshi S, Maheshwari A. Malposition of a nasogastric tube. Ann Card Anaesth. 2015;18(2): 2723. doi: https://doi.org/10.4103/0971-9784.154502

56. Andresen EN, Frydland M, Usinger L. Deadly pressure pneumothorax after withdrawal of misplaced feeding tube: a case report. J Med Case Rep. 2016;10(30). doi: https://doi.org/10.1186/s13256-016-0813-y

57. Kao X, Yu W, Zhu W, Li N, Li J. Repeated lung lavage with extracorporeal membrane oxygenation treating severe acute respiratory distress syndrome due to nasogastric tube malposition for enteral nutrition: a case report. Asia Pac ] Clin Nutr. [Internet]. 2012 [cited May 24, 2019];21(4):638-41. Available from: http://apjcn. nhri.org.tw/server/APJCN/21/4/638.pdf

58. Leonard S, O'Connell S, O'Connor M. Complications of nasogastric tube placement - don't blow it. Ir Med J. [Internet]. 2012 [cited May 24, 2019];105(4):116-7. Available from: https://pdfs.semanticscholar.org/024a/ 52e54b31c39b0d3a458a6b4b3dc8e35e0671.pdf

59. Paul V, Shenoy A, Kupfer Y, Tessler S. Pneumothorax occurring after nasogastric tube removal. BMJ Case Reports. 2013;2013:bcr2013010419. doi: https://doi. org/10.1136/bcr-2013-010419

60 . James RH. An unusual complication of passing a narrow bore nasogastric tube. Anaesthesia. 1978;33(8):7168. doi: https://doi.org/10.1111/j.1365-2044.1978. tb08467.x

61. Duthorn L, Schulte Steinberg H, Hauser H, Neeser G, Pracki P. Accidental intravascular placement of feeding tube. Anesthesiology. 1998;89(1):251-3. doi: https:// doi.org/10.1097/00000542-199807000-00031

62. Isozaki E, Tobisawa S, Naito R, Mizutani T, Hayashi $\mathrm{H}$. A variant form of nasogastric tube syndrome. Intern Med. 2005;44(12):1286-90. doi: https://doi. org/10.2169/internalmedicine.44.1286

63. Wu PY, Kang TJ, Hui CK, Hung MH, Sun WZ, Chan WH. Fatal massive hemorrhage caused by nasogastric tube misplacement in a patient with mediastinitis. J Formos Med Assoc. 2006;105(1):80-5. doi: https://doi. org/10.1016/S0929-6646(09)60113-3

64. Campo BV, Pérez DM, Garrido DS. Nasogastric tube syndrome: a case report. Acta Otorrinolaringol Esp. 2010;61(1):85-6. doi: https://doi.org/10.1016/j. otorri.2009.03.006

65. Sankar V, Shakeel M, Keh S, Ah-See KW. A case of a "lost" nasogastric tube. J Laryngol Otol. 2012;126(12):1296-8. doi: https://doi.org/10.1017/ S0022215112002447

66. Cereda E, Costa A, Caccialanza R, Pedrolli C. A malfunctioning nasogastric feeding tube. Nutr Hosp. 2013;28(1):229-31. doi: https://doi.org/10.3305/ nh.2013.28.1.6259
67. Khasawneh FA, Al-Janabi MG, Ali AH. Nasopharyngeal perforation by a new electromagnetically visualised enteral feeding tube. BMJ Case Rep. 2013;2013. pii: bcr2013009807. doi: https://doi.org/10.1136/bcr2013-009807

68. Cervo AS, Magnago TSBS, Carollo JB, Chagas BP, Oliveira AS, Urbanetto JS. Adverse events related to the use of enteral nutritional therapy. Rev Gaúcha Enferm. 2014;35(2):53-9. doi: http://dx.doi.org/10.1590/1983$\underline{1447.2014 .02 .4239670}$

69. Tawfic QA, Bhakta P, Date RR, Sharma PK. Esophageal bezoar formation due to solidification of enteral feed administered through a malpositioned nasogastric tube: case report and review of the literature. Acta Anaesthesiol Taiwan. 2012;50(4):188-90. doi: https:// doi.org/10.1016/j.aat.2012.12.002

70. Van Dinter Jr TG, John L, Guileyardo JM, Fordtran JS. Intestinal perforation caused by insertion of a nasogastric tube late after gastric bypass. Proc (Bayl Univ Med Cent). 2013;26(1):11-5. doi: https://doi.org/ 10.1080/08998280.2013.11928900

71. Wyler AR, Reynolds AF. An intracranial complication of nasogastric intubation case report. J Neurosurg. 1977;47(2):297-8. doi: https://doi.org/10.3171/ jns. 1977.47.2.0297

72. Glasser SA, Garfinkle W, Scanlon M. Intracranial complication during insertion of a nasogastric tube. AJNR Am J Neuroradiol. [Internet]. 1990 [cited May 24, 2019];11(6):1170. Available from: http://citeseerx.ist. psu.edu/viewdoc/download?doi=10.1.1.842.9602\&rep $=$ rep $1 \&$ type $=$ pdf

73. Freij RM, Mullett ST. Inadvertent intracranial insertion of a nasogastric tube in a non-trauma patient. J Accid Emerg Med. 1997;14(1):45-7. doi: https://doi. org/10.1136/emj.14.1.45

74. Ferreras J, Junquera LM, Garcia-Consuegra L. Intracranial placement of a nasogastric tube after severe craniofacial trauma. Oral Surg Oral Med Oral Pathol Oral Radiol Endod. 2000;90(5):564-6. doi: https://doi. org/10.1067/moe.2000.110032

75. Genu PR, Oliveira DM, Vasconcellos RJ, Nogueira RV, Vasconcelos BC. Inadvertent intracranial placement of a nasogastric tube in a patient with severe craniofacial trauma: a case report. J Oral Maxillofac Surg. 2004;62(11):1435-8. doi: https://doi.org/10.1016/j. joms.2004.07.005

76. Carrion MI, Ayuso D, Marcos M, Paz Robles M, de la Cal MA, Alia I, et al. Accidental removal of endotracheal and nasogastric tubes and intravascular catheters. Crit Care Med. 2000;28(1):63-6. doi: https://doi. org/10.1097/00003246-200001000-00010

77. Nascimento CCP, Toffoletto MC, Gonçalves LA, Freitas WG, Padilha KG. Indicators of healthcare results: 
analysis of adverse events during hospital stays. Rev. Latino-Am. Enfermagem. 2008;16(4):746-51. doi: http://dx.doi.org/10.1590/S0104-11692008000400015 78. Güimil JAE, Dios MJP, Camiña MCF, Ucha MCG, Pastoriza MDV, Fernández CR, et al. Úlceras por presión iatrogénicas de localización nasal. Gerokomos. [Internet]. 2010 [acceso 24 mayo 2019];21(1):29-36. Disponible en: http://scielo.isciii.es/scielo.php?script=sci_ arttext\&pid=S1134-928X2010000100005\&Ing=es

79. Ghahremani GG, Gould RJ. Nasoenteric feeding tubes. Radiographic detection of complications. Dig Dis Sci. 1986;31(6):574-85. doi: https://doi.org/10.1007/ bf01318688

80. Takeshita H, Yasuda T, Nakajima T, Mori S, Mogi K, Ohkawara $\mathrm{H}$, et al. A death resulting from inadvertent intravenous infusion of enteral feed. Int J Legal Med. 2002;116(1):36-8. doi: https://doi.org/10.1007/ s004140000186

81. Roberts TCN, Swart M. Enteral drugs given through a central venous catheter. Anaesthesia. 2007;62(6):624-6. doi: https://doi.org/10.1111/ j.1365-2044.2007.05108.x

82. Thorat JD, Wang E. Gastric acid burns because of a disconnected nasogastric tube. CMAJ. 2008;178(6):680. doi: https://doi.org/10.1503/cmaj.070864

83. Millin $\mathrm{CJ}$, Brooks M. Device safety. Reduce and report - enteral feeding tube misconnections. Nursing. 2010;40(11):59-60. doi: 10.1097/01. NURSE.0000389035.64254.9b

84. Lyman B, Peyton C, Healey F. Reducing nasogastric tube misplacement through evidence-based practice: is your practice up-to-date? Am Nurse Today. [Internet]. 2018 [cited May 24, 2019];13(11):6-11. Available from: https://www.americannursetoday.com/reducingnasogastric-tube-misplacement/

85. Al Saif N, Hammodi A, Al-Azem MA, Al-Hubail R. Tension pneumothorax and subcutaneous emphysema complicating insertion of nasogastric tube. Case Rep Crit Care. 2015;2015:690742. doi: https://doi. org/10.1155/2015/690742

86. Sparks DA, Chase DM, Coughlin LM, Perry E. Pulmonary complications of 9931 narrow-bore nasoenteric tubes during blind placement: a critical review. JPEN J Parenter Enteral Nutr. 2011;35(5):625-9. doi: 10.1177/0148607111413898

87. NHS Improvement. Resource set: initial placement checks for nasogastric and orogastric tubes. [Internet]. London: NHS Improvement; 2016 [cited May 24, 2019]. Available from: https://improvement.nhs.uk/ documents/193/Resource_set_-_Initial_placement_ checks_for_NG_tubes_1.pdf

88. AACN Practice alert. Initial and ongoing verification of feeding tube placement in adults (applies to blind insertions and placements with an electromagnetic device). Crit Care Nurse. 2016;36(2):e8-e13. doi: https://doi.org/10.4037/ccn2016141

89. Brousseau VJ, Kost KM. A rare but serious entity: nasogastric tube syndrome. Otolaryngol Head Neck Surg. 2006;135(5):677-9. doi: https://doi.org/10.1016/j. otohns.2006.02.039.

90. Alva S, Eisenberg D, Duffy A, Roberts K, Israel G, Bell R. Virtual three-dimensional computed tomography assessment of the gastric pouch following laparoscopic Roux-Y gastric bypass. Obes Surg. 2008;18(4):364-6. doi: https://doi.org/10.1007/s11695-008-9438-6 91. Viana RAPP, Rezende E, Batista MAO, Silva CM, Ribeiro Neto MC, Setoyama TA, et al. Efetividade da sondagem pós-pilórica usando guia magnético. Rev Bras Ter Intensiva. 2011;23:49-55. doi: http://dx.doi. org/10.1590/S0103-507X2011000100009

92. Kim J, Shin JH. Placement of feeding tubes using fluoroscopy guidance and over-the-wire technique: a technical review. Gastrointest Interv. 2017;6:135-9. doi: https://doi.org/10.18528/gii160022

93. Byrne KR, Fang JC. Endoscopic placement of enteral feeding catheters. Curr Opin Gastroenterol. 2006;22(5):546-50. doi: https://doi.org/10.1097/01. mog.0000239871.12081.7f

94. Niv E, Fireman Z, Vaisman N. Post-pyloric feeding. World J Gastroenterol. 2009;15(11):1281-8. doi: https://doi.org/10.3748/wjg.15.1281

95. Prabhakaran S, Doraiswamy VA, Nagaraja V, Cipolla J, Ofurum U, Evans DC, et al. Nasoenteric tube complications. Scand J Surg. 2012;101(3):147-55. doi: https://doi.org/10.1177/145749691210100302

96. Stewart ML. Interruptions in enteral nutrition delivery in critically ill patients and recommendations for clinical practice. Crit Care Nurse. 2014;34(4):14-21. doi: https://doi.org/10.4037/ccn2014243.

97. Degheili JA, Sebaaly MG, Hallal AH. Nasogastric tube feeding-induced esophageal bezoar: case description. Case Rep Med. 2017;2017:1-4. doi: https://doi. org/10.1155/2017/1365736

98. Gimenes FRE, Pareira RA, Horak ACP, Oliveira CC, Reis AMM, Silva PCS, et al. Medication incidents related to feeding tube: a cross-sectional study. Afr J Pharm Pharmacol. 2017;11(27):305-13. doi: https://doi. org/10.5897/AJPP2017.4799

99. Pereira SRM, Mesquita AMF, Teixeira AO, Graciano SA, Coelho MJ. Causas da retirada não planejada da sonda de alimentação em terapia intensiva. Acta Paul Enferm. 2013;26(4):338-44. doi: http://dx.doi.org/10.1590/ S0103-21002013000400007

100. McGinnis C. The feeding tube bridle: one inexpensive, safe, and effective method to prevent inadvertent feeding 
tube dislodgement. Nutr Clin Pract. 2011;26(1):70-7. doi: https://doi.org/10.1177/0884533610392585

101. Brazier S, Taylor SJ, Allan K, Clemente R, Toher D. Stroke: ineffective tube securement reduces nutrition and drug treatment. $\mathrm{Br}$ J Nurs. 2017;26(12):656-63. doi: https://doi.org/10.12968/bjon.2017.26.12.656.

102. Seyedhejazi M, Hamidi M, Sheikhzadeh D, Aliakbari Sharabiani B. Nasogastric tube placement errors and complications in pediatric intensive care unit: a case report. J Cardiovasc Thorac Res. 2011;3(4):133-4. doi: https://doi.org/10.5681/jcvtr.2011.029.

103. Bozzetti V, Barzaghi M, Ventura ML, Tagliabue PE. Impact of a dedicated enteral feeding system in an Italian NICU. JPEN J Parenter Enteral Nutr. 2014;38(4):510-2. doi: https://doi.org/10.1177/0148607113487562

104. TJC: plan and prepare for the transition to new tubing connectors to minimize the risk of dangerous misconnections, clinician frustration. ED Manag. 2014;26(12): Suppl 1-3.

105. Guenter P, Lyman B. ENFit enteral nutrition connectors. Nutr Clin Pract. 2016;31(6):769-72. doi: https://doi.org/10.1177/0884533616673638 Creative Commons (CC BY).

This license lets others distribute, remix, tweak, and build upon your work, even commercially, as long as they credit you for the original creation. This is the most accommodating of licenses offered. Recommended for maximum dissemination and use of licensed materials. 